\title{
SR-IMS Molecular Spectroscopic Image of Functional Groups in Biopolymers in Feed Systems
}

\author{
Peiqiang $\mathrm{Yu}$ \\ College of Agriculture and Bioresources, University of Saskatchewan, \\ Canada
}

\section{Introduction}

\subsection{Powerful SR-IMS research tool for imaging in complex feed systems}

Advanced ultra-spatially resolved synchrotron-radiation Fourier transform infrared micorspectroscopy (SR-IMS) has been developed as a bioanalytically probing technique to study biomaterials at cellular and molecular levels within intact tissue (1-3). This technique, taking advantage of bright synchrotron light which is millions time brighter than sunlight, is able to provide four kind of information simultaneously: tissue chemistry, tissue composition, tissue environment and tissue structure $(4,5)$.

Compared with conventional chemical analysis in the lab, this technique can link chemical information to structure information without destruction of original structure information. No harsh chemicals are involved. The use of harsh chemicals and derivatization can result in altering the native structures and possibly generating artifacts in complex plant system (5).

\subsection{Objective}

The objective of this study was to use the advanced ultra-spatially resolved synchrotron radiation-based infrared microspectroscopy (SR-IMS) as a non-invasive and non-destructive tool to study microstructural features of the embryo (germ) in sorghum (Sorghum bicolor L.) seeds within cellular dimension within intact embryo tissue.

\section{Materials ahd methods}

\subsection{Seed embryo tissue preparation and synchrotron FTIR window}

Sorghum seed (feed-type), obtained from Dr. Liu Dasen (Northeast Agriculture University, China), were cut into thin cross sections (6 $\mu$ m thick) using a microtome at The Western College of Veterinary Medicine, University of Saskatchewan and then transferred to BaF2 windows (size: $13 \times 1 \mathrm{~mm}$ disk; Spectral Systems, NY) for transmission mode synchrotron FTIR microspectroscopic work.

\subsection{Synchrotron light source and synchrotron-based IR microspectroscopy}

The experiment was carried out on U2B beamline at the National Synchrotron Light Source located in Brookhaven National Laboratory (NSLS-BNL, U.S. Department of Energy, New 
York). The beamline was equipped with a FTIR spectrometer (Nicolet Magna 860) with KBr beamsplitter and a mercury cadmium telluride (MCT-A) detector coupled with an infrared microscope (Nic-Plan ${ }^{\mathrm{TM}}$, Nicolet Instruments, Madison, WI). The bench was configured to use collimated synchrotron light (beam energy $800 \mathrm{MeV}$ ) through an external input of the spectrometer. The modulated light was passed through the Nic-Plan TM IR microscope to perform reflection microscopy. The infrared spectra were collected in the mid-IR range 4000$800 \mathrm{~cm}^{-1}$ at a resolution of $4 \mathrm{~cm}^{-1}$ with 64 scans co-added and an aperture setting of ca. $10 \mu \mathrm{m}$ $\times 10 \mu \mathrm{m}$. This size was within cellular dimension and was the best for getting good signal to noise ratio spectrum mapping in complex plant system. To minimize IR absorption by $\mathrm{CO}_{2}$ and water vapour in ambient air, the optics were purged using dry $\mathrm{N}_{2}$. A background spectroscopic image file was collected from an area free of sample. The mapping steps were equal to aperture size. Stage control, data collection and processing were performed using OMNIC 7.2 (Thermo-Nicolet, Madison, Wisconsin). Scanned visible images were obtained using a charge-coupled device (CCD) camera linked to the infrared images (objective $\times 32)(6)$.

\subsection{Molecular spectral data analysis and imaging of molecular chemistry}

The spectral data of the tissues were collected and analyzed after the correction of the background spectrum using OMNIC software 7.2 (Thermo-Nicolet, Madison, Wisconsin). The data can be displayed as either as a series of spectroscopic images collected at individual wavelength, or as a collection of infrared spectra obtained at each pixel position in the image.

Molecular chemistry of functional groups was imaged under the peaks at ca. 1650, 1628, 1550, 1067, 1186-950, 2956, and $2920 \mathrm{~cm}^{-1}$ using the OMNIC software 7.2 (Thermo-Nicolet, Madison, Wisconsin). The functional groups peak assignments were from publications (7-14).

Peak ratio images of molecular functional groups, representing the distribution and intensity of the functional group in the tissue, were obtained by dividing the area under one molecular functional group band (eg. amide I ca. $1650 \mathrm{~cm}^{-1}$ ) by the area under another molecular functional group band (eg. $\mathrm{CHO} 1067 \mathrm{~cm}^{-1}$ ) at each pixel (pixel size 10×10 $\left.\mu \mathrm{m}\right)(6)$. The false color maps were used (colors representing band intensities), which were derived from the area under particular spectral features

\section{Results and discussion}

\subsection{Spectral characteristics and photomicrograph of the embryo tissues in sorghum saeed}

Figure 1 illustrates the inherent structure of embryo tissue in sorghum seeds $(6 \mu \mathrm{m}$-thickness cross-section). Whole seed tissue includes pericarp, aleurone cell layer, subendosperm, endosperm and embryo (germ) regions which is typical for the cereal grain seeds (4). The figure is embryo region. It is a very unique from visible image. However, the detailed chemistry of embryo tissue in its original form in sorghum seed is not fully understood due to limited analytical technique available before available synchrotron-based technique (2). The photomicrographs of the tissue are not informative with respect to molecular chemical features of the inherent structures at spatial resolution (6). We need an advanced analytical technique which can be used for us to "see" complex chemical information in its original tissue. The synchrotron based technique (SR-IMS) could be used to image molecular chemistry in complex plant system $(4,6)$. This technique enables to collect the spectral data at the diffraction limit or a few microns without destruction of inherent tissue structure $(1,3,4)$, which is not possible to use previous techniques. 


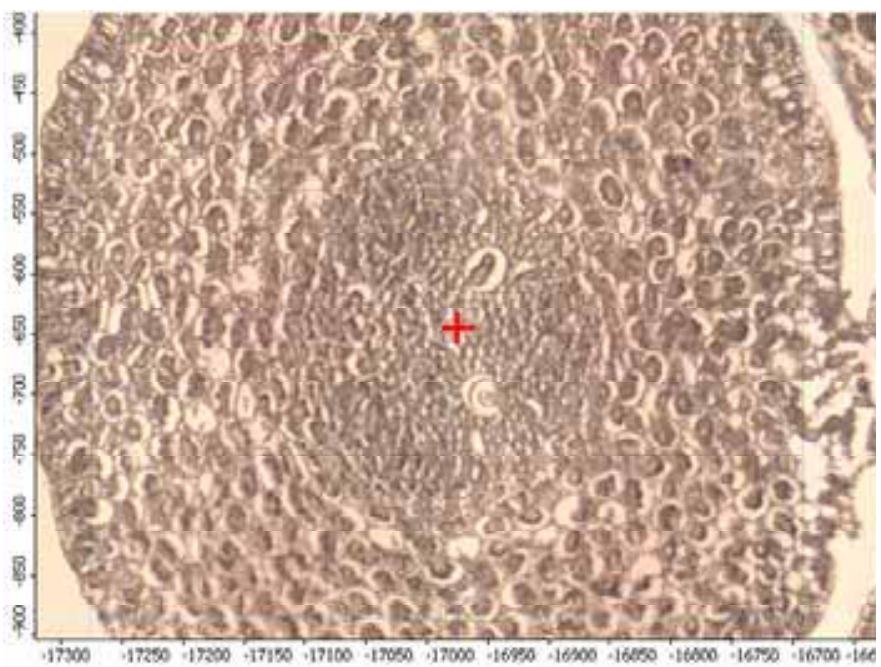

Fig. 1. Photomicrograph of cross-section of the enlarged embryo (germ) tissue in whole sorghum seeds $(6 \mu \mathrm{m})$ showing the intrinsic visible structure of sorghum germ.

Figure 2 presents a typical spectrum (pixel size: $10 \times 10 \mu \mathrm{m}$ ) from the sorghum embryo tissue, showing broad N-H and O-H stretching band at ca. $3270 \mathrm{~cm}^{-1}, \mathrm{CH}_{2}$ and $\mathrm{CH}_{3}$ anti-symmetric and symmetric stretching bands at the region of ca. $2990-2780 \mathrm{~cm}^{-1}$, amide I and II bands at ca. $1650 \mathrm{~cm}^{-1}$ and $1550 \mathrm{~cm}^{-1}$, respectively and cellulosic compound bands region of ca. 1200$800 \mathrm{~cm}^{-1}$, using ultra-spatially resolved synchrotron-based FTIR microspectroscopy. From these functional groups bands, we can see the embryo tissue has complex plant system.

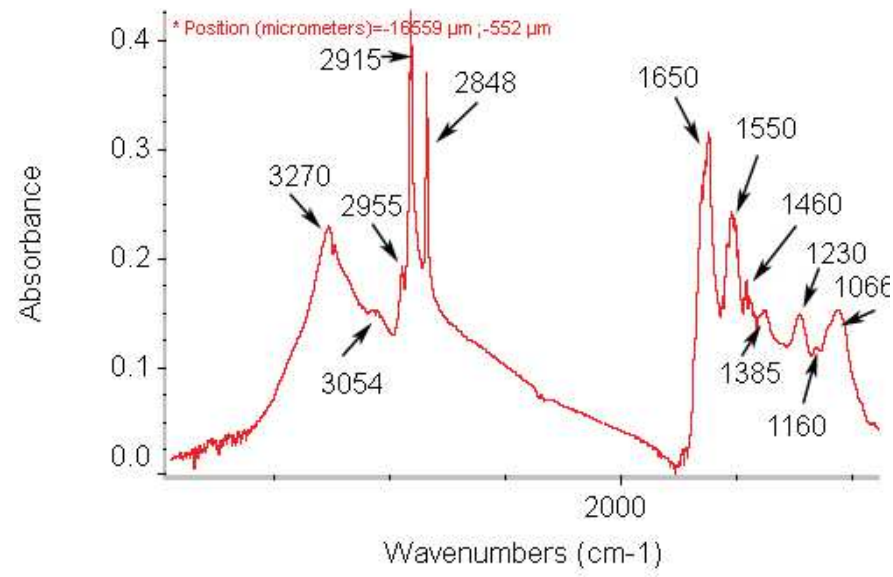

Fig. 2. Typical spectrum of sorghum germ tissue within cellular and sub-cellular dimensions showing broad N-H and O-H stretching band at ca. $3270 \mathrm{~cm}^{-1}, \mathrm{CH}_{2}$ and $\mathrm{CH}_{3}$ anti-symmetric and symmetric stretching bands at the region of ca. $2990-2780 \mathrm{~cm}^{-1}$, amide I and II bands at ca. $1650 \mathrm{~cm}^{-1}$ and $1550 \mathrm{~cm}^{-1}$, respectively and cellulosic compound bands region of ca. 1200$800 \mathrm{~cm}^{-1}$, using ultra-spatially resolved synchrotron-based FTIR microspectroscopy at National Synchrotron Light Source, Brookhaven National Lab (U.S. Dept of Energy, NY). 
Figure 3 shows the molecular spectra of sorghum seed germ tissues randomly selected from the corresponding area from the visible image (spectra corresponding to the pixel at the cross-hair in the visible image). From the figure, it is clear to show that the embryo (germ) tissue contained extremely high $\mathrm{CH}_{3}$ anti-symmetric, $\mathrm{CH}_{2}$ anti-symmetric, $\mathrm{CH}_{3}$ symmetric and $\mathrm{CH}_{2}$ symmetric stretching bands $(1,3,4)$. These bands are highly associated mainly with lipid and minor with protein (15). The embryo tissue also contains high amide I and amide II bands $(2,8,9)$, indicated high protein composition in the embryo. From the pixel spectra pattern, it was found that sorghum embryo contains relatively high protein beta-sheet (ca. $1628 \mathrm{~cm}^{-1}$ ). It also contains low cellulosic compounds in the tissue. The results also show that that similar morphological part - embryo (germ) exhibits similar spectral characteristics but different spectral intensities.

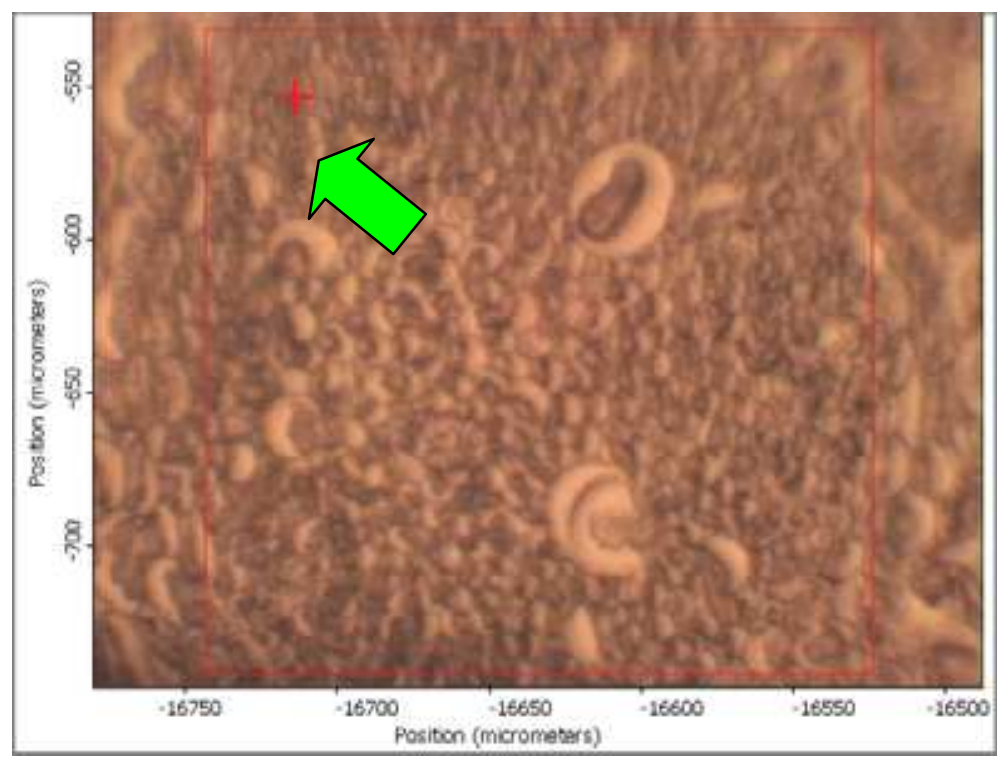

Pixel 1 in sorghum germ tissue

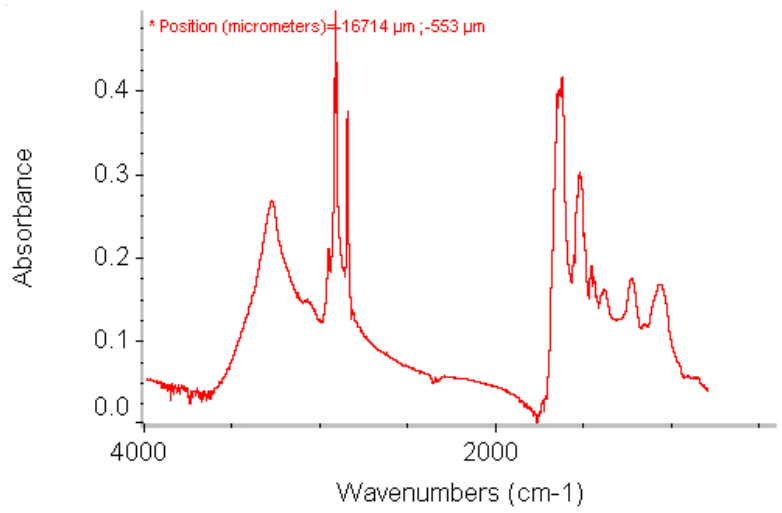

Spectra corresponding to the pixel 1 at the cross-hair in the visible image 


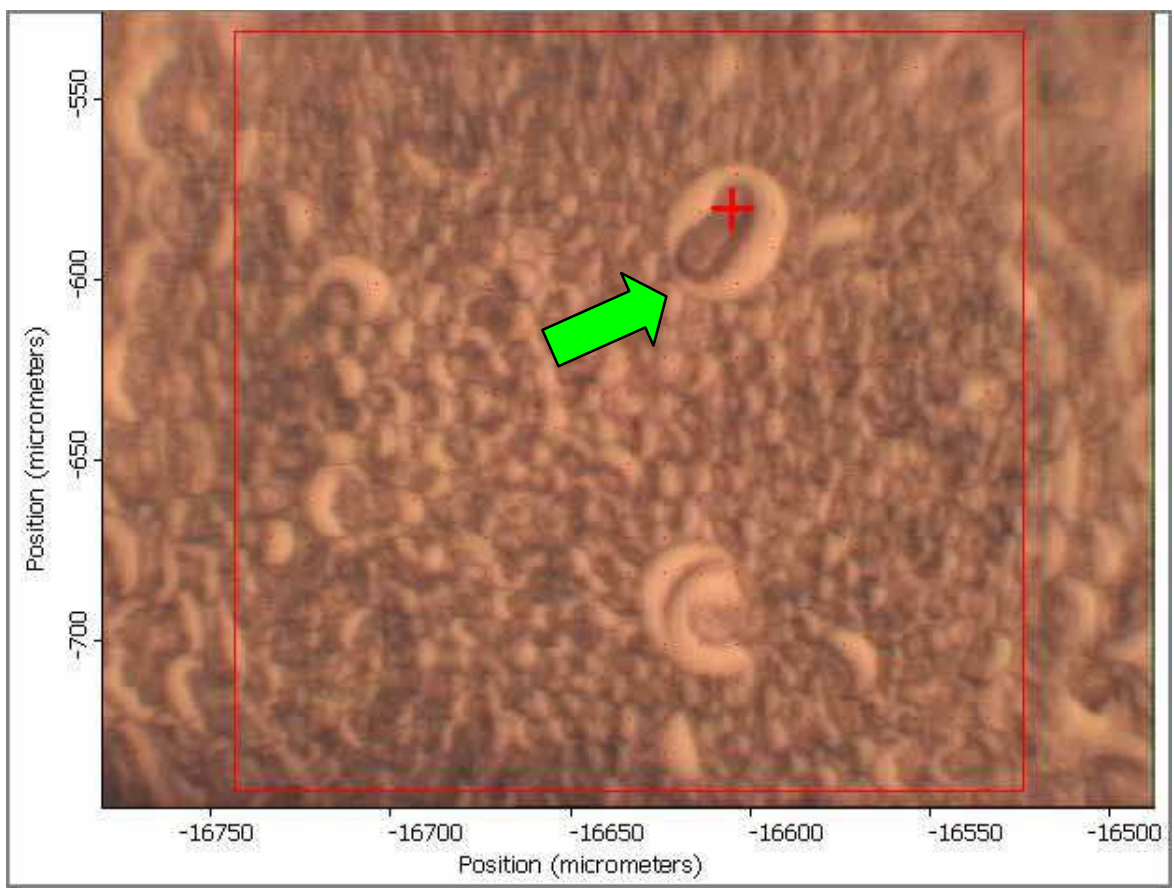

Pixel 2 in sorghum germ tissue

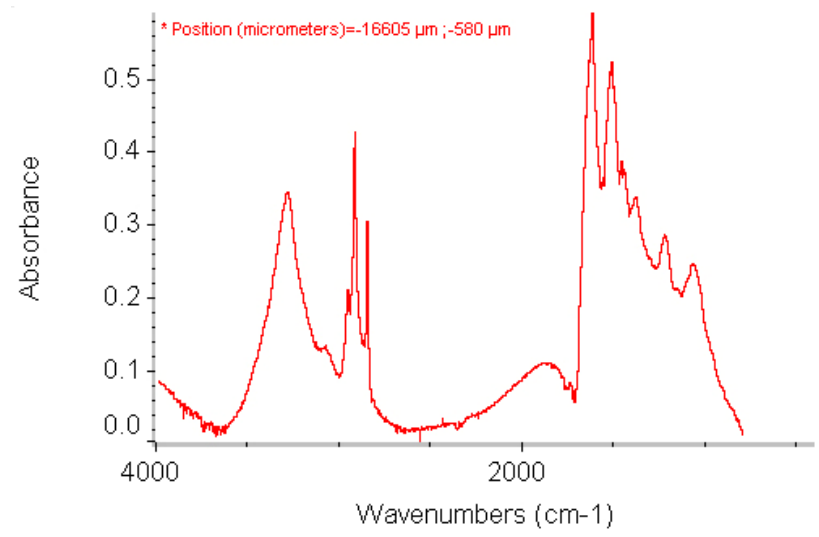

Spectra corresponding to the pixel 2 at the cross-hair in the visible image 


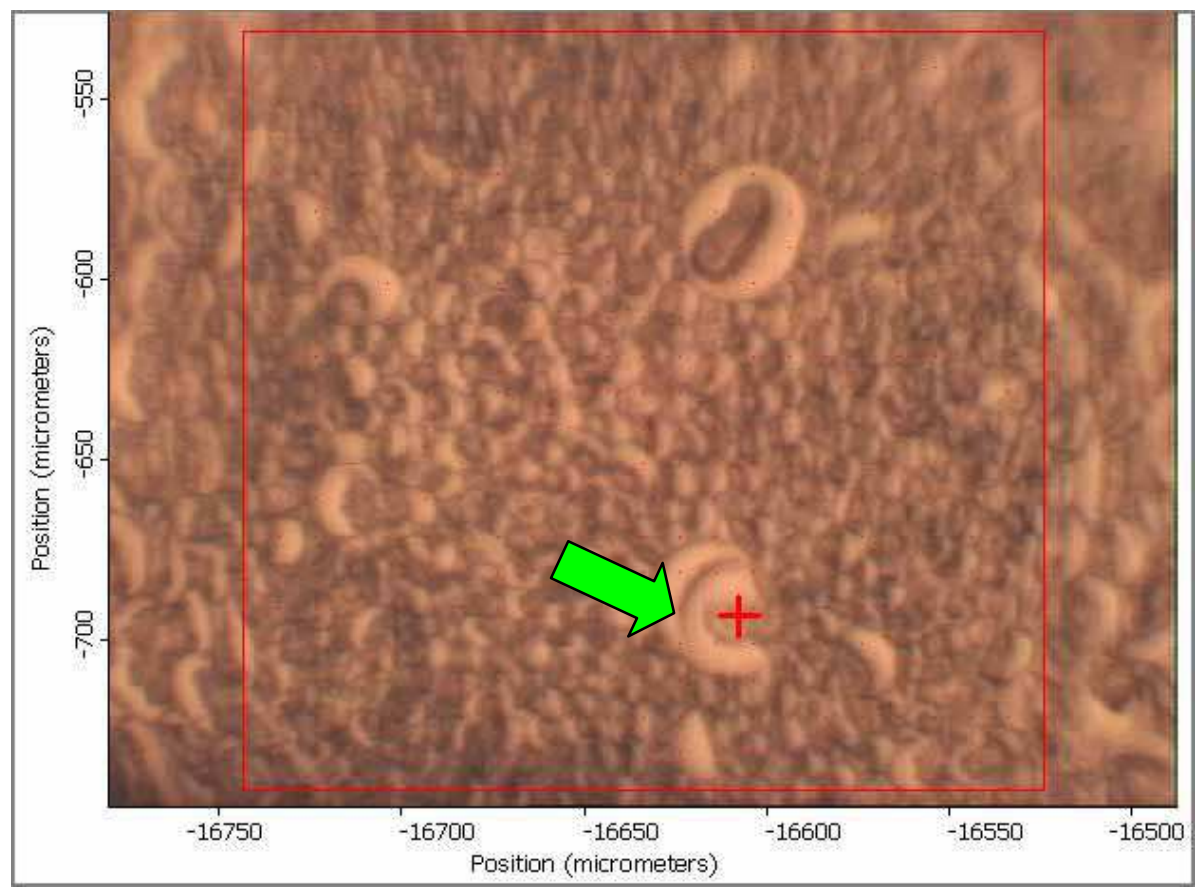

Pixel 3 in sorghum germ tissue

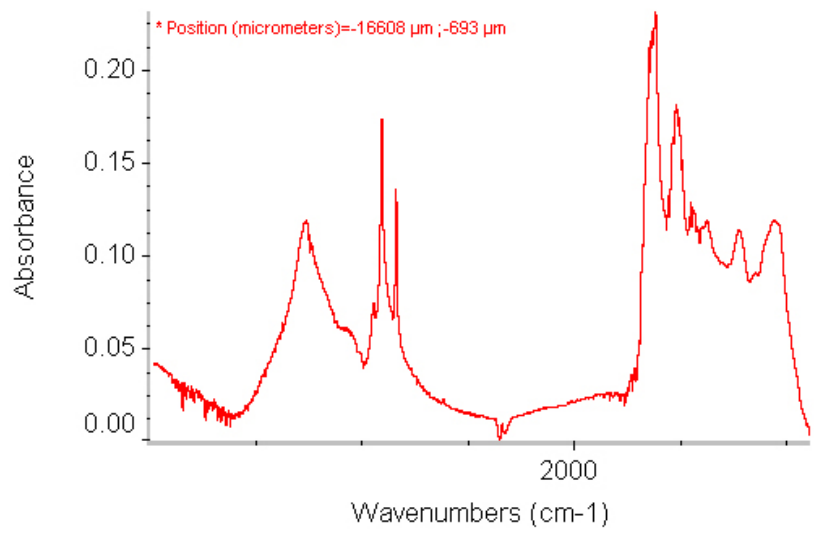

Spectra corresponding to the pixel 3 at the cross-hair in the visible image 


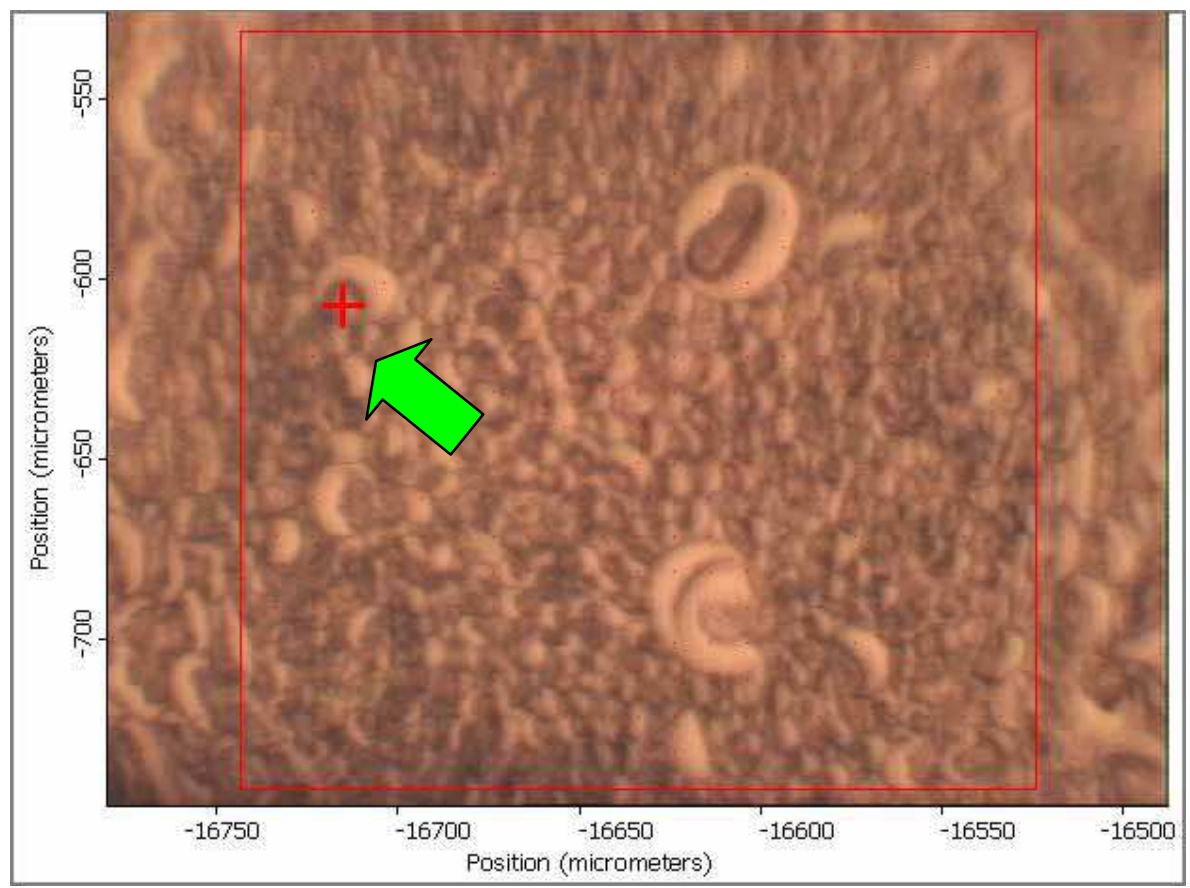

Pixel 4 in sorghum germ tissue

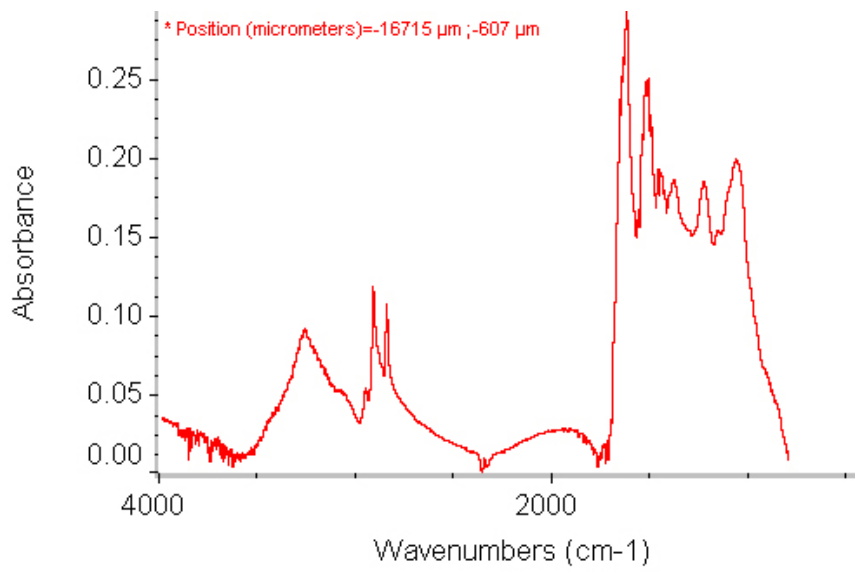

Spectra corresponding to the pixel 4 at the cross-hair in the visible image 


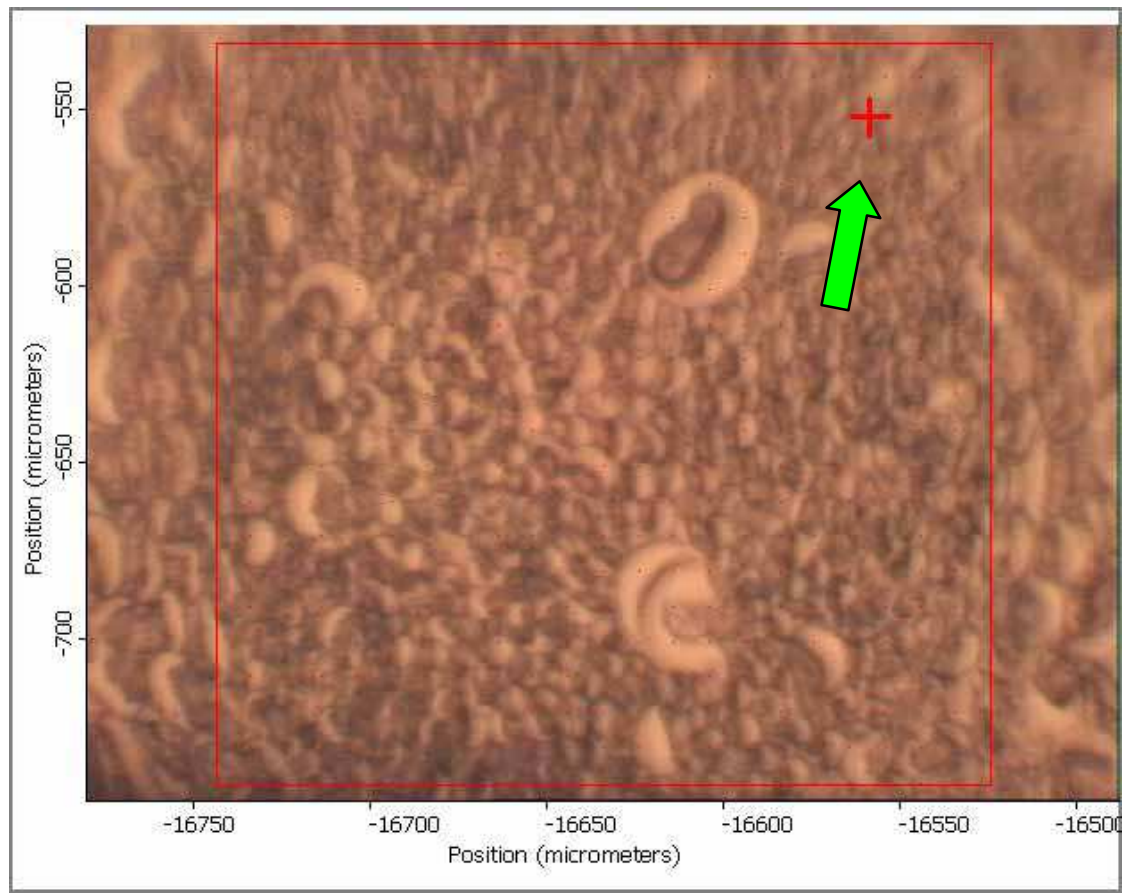

Pixel 5 in sorghum germ tissue

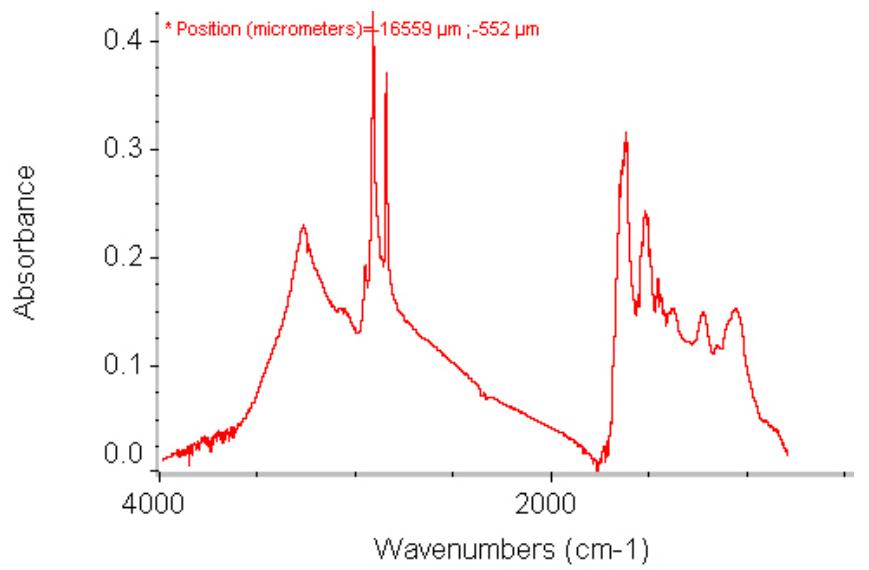

Spectra corresponding to the pixel 5 at the cross-hair in the visible image

Fig. 3. Molecular spectra (pixel size $10 \times 10 \mu \mathrm{m}$ ) of sorghum seed germ tissues randomly selected from corresponding area from the visible images, showing that similar morphological parts exhibit similar spectral characteristics but different spectral intensities, ultra-spatially resolved synchrotron-based FTIR microspectroscopy at National Synchrotron Light Source, Brookhaven National Lab (U.S. Dept of Energy, NY) 


\subsection{Detect the microstructural features through molecular chemistry mapping of functional groups}

The big advantage of the synchrotron-based technique-SR-IMS is able to image the tissue chemistry at an ultra-spatial resolution. It can reach diffraction limit (a few microns) without damage of the original tissue structure. Electric microscopy (EM) can only give us a visible image, not chemical image. We cannot get any chemical sense from EM technique. Figure 4 represents color maps of functional groups of sorghum embryo tissue and each single pixel size was $10 \times 10 \mu \mathrm{m}$. The Figure 4 shows visible, chemical and three-D images in false-color representation of chemical component intensities, and spectra at various pixels in the embryo tissue. The results clearly show that with the SR-IMS, the distribution, intensity and relative concentration of the chemical functional groups associated with the inherent structure could be imaged. The images were taken from the region of the visible image outlined by the rectangle area. The molecular functional groups were imaged under either functional group infrared peak height or area, such as amide I intensity image (ca. $1650 \mathrm{~cm}^{-1}$ ) in Figure 4(a), cellulosic compounds (ca. 1420-1330 cm-1) intensity image in Figure 4(b), total carbohydrate image (ca. 1185-950 $\mathrm{cm}^{-1}$ ) in Figure 4(d), protein beta-sheet structure image (ca. $1628 \mathrm{~cm}^{-1}$ ) in Figure 4(d), $\mathrm{CH}$ stretching bands (ca. 2800-3000 $\left.\mathrm{cm}^{-1}\right)$ image $\left(\mathrm{CH}_{3}\right.$ and $\mathrm{CH}_{2}$ groups of the acyl chains) in Figure 4(e), as well as $\mathrm{CH}_{3}$ (ca. $2956 \mathrm{~cm}^{-1}$ ) and $\mathrm{CH}_{2}$ antisymmetric stretching bands (ca. $2920 \mathrm{~cm}^{-1}$ ) in Figure $4(\mathrm{f}, \mathrm{g})$.

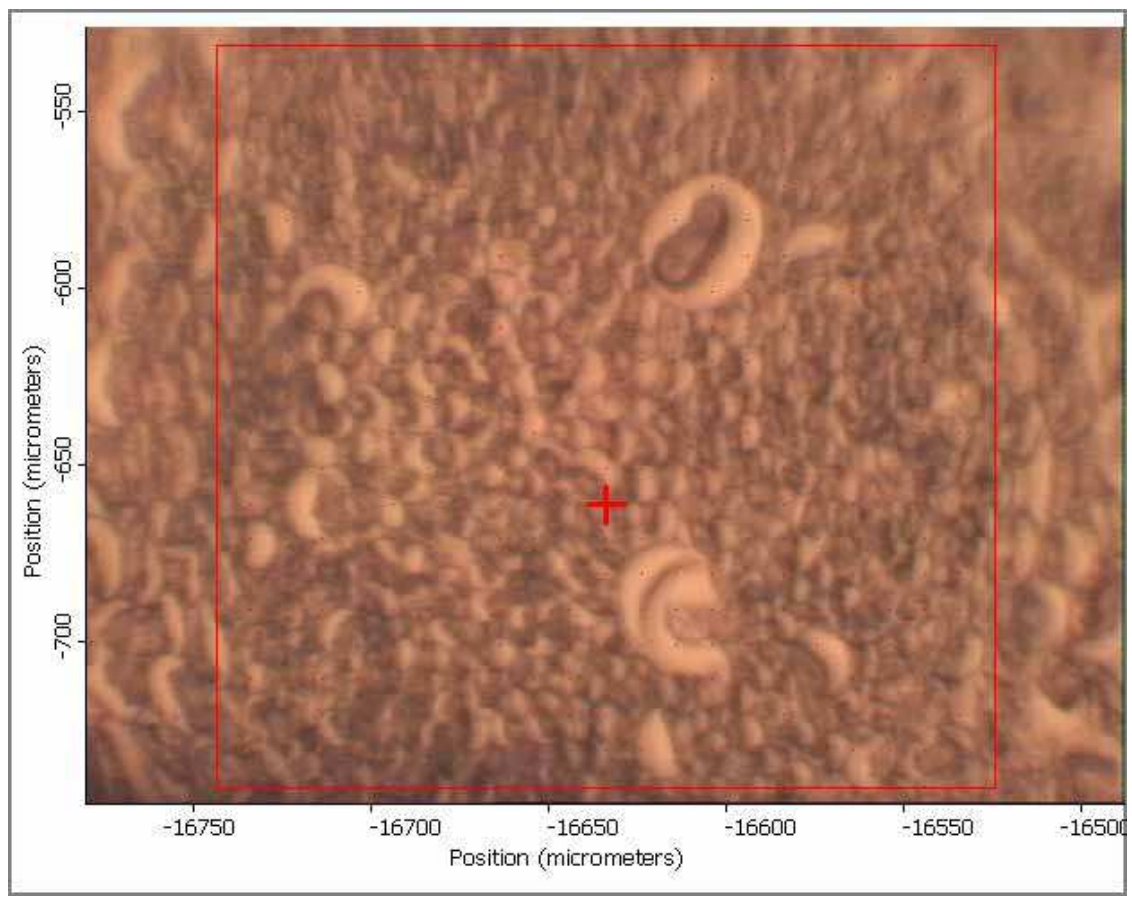

Visible image of selected germ area in sorghum seeds 
(a)

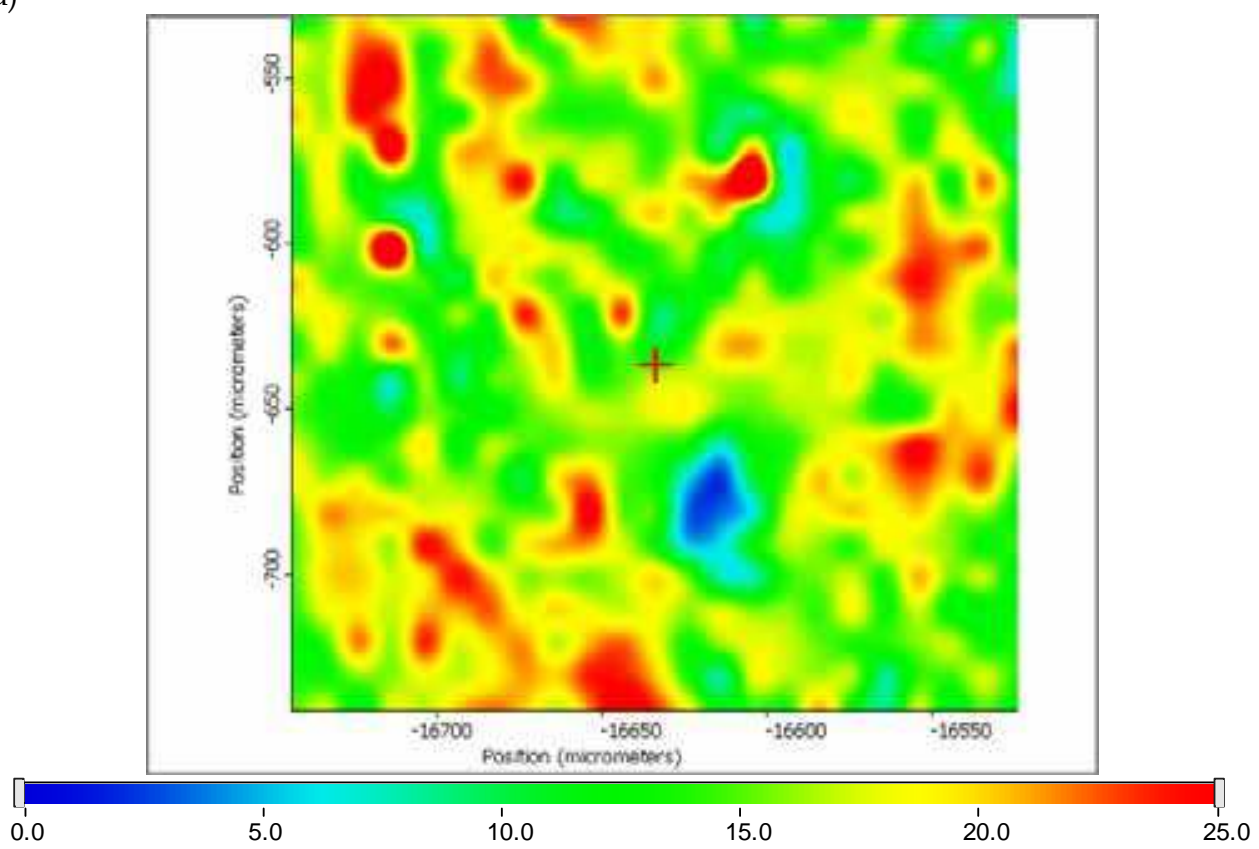

ca. $1650 \mathrm{~cm}^{-1}$ (Chemical image; Ruler showing chemical intensity)

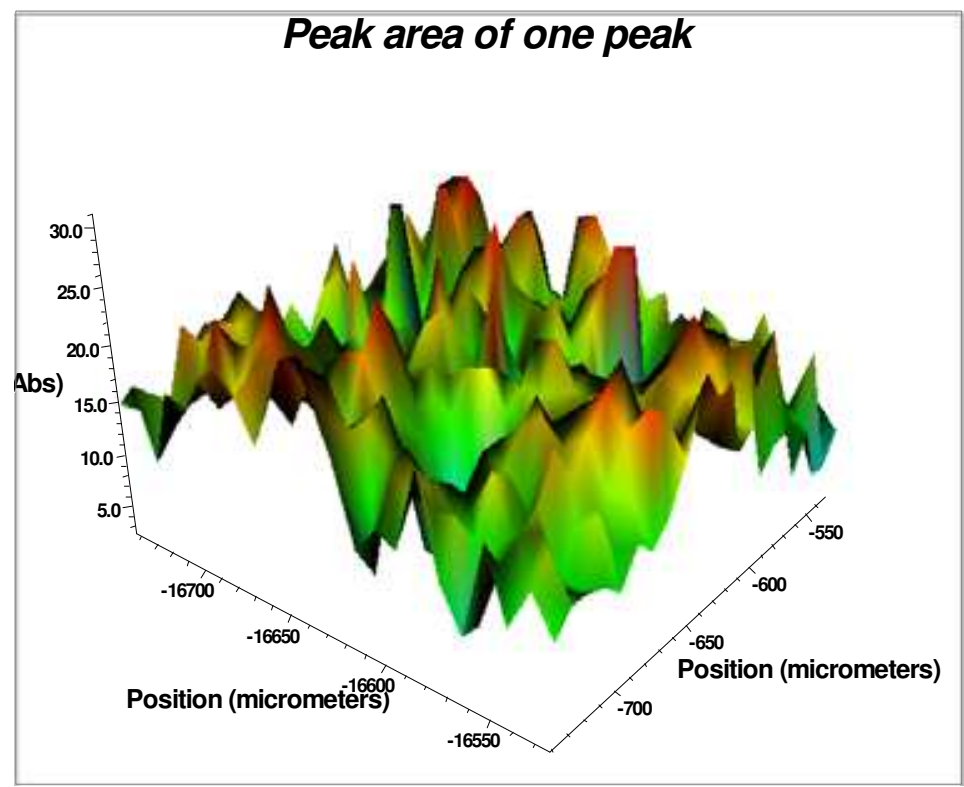

ca. $1650 \mathrm{~cm}^{-1}$ (3D image) 
(b)

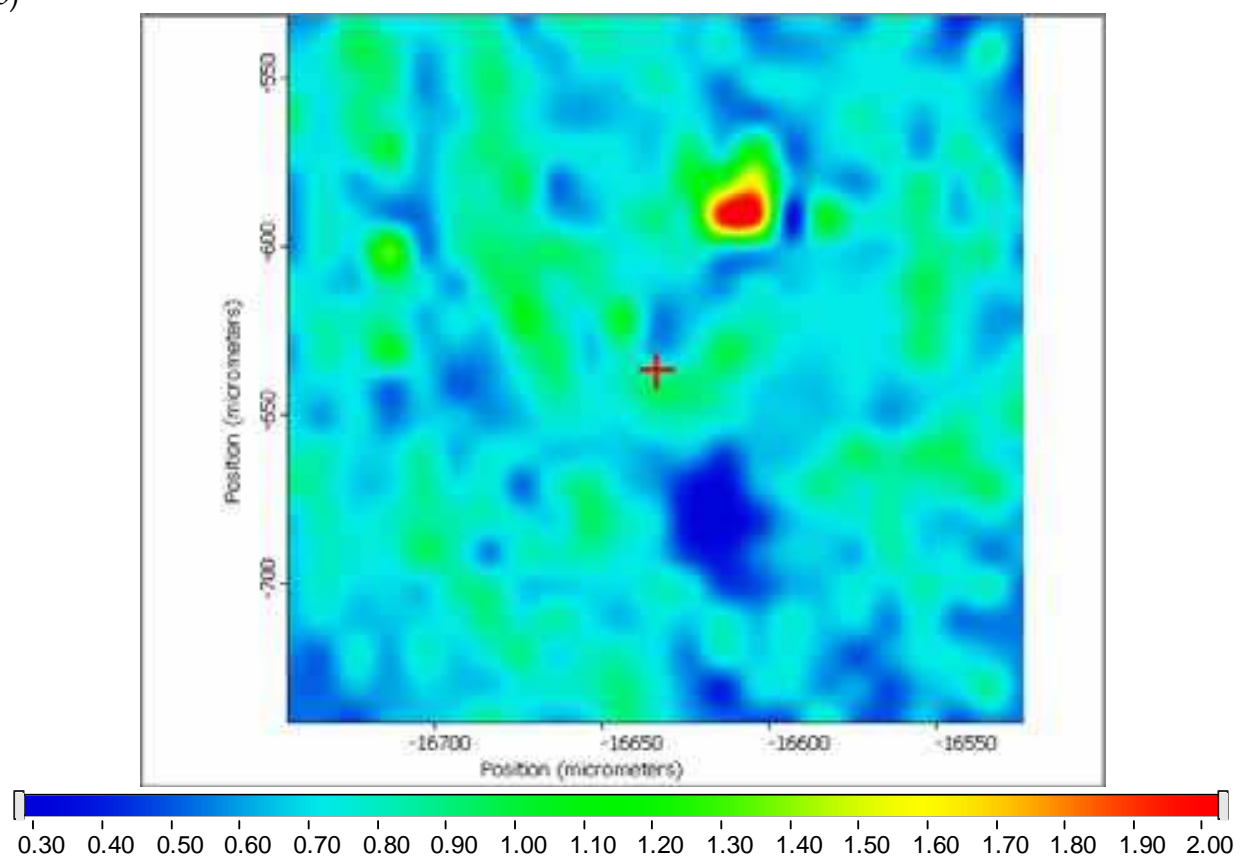

ca. $1420-1330 \mathrm{~cm}^{-1}$ (Chemical image; Ruler showing chemical intensity)

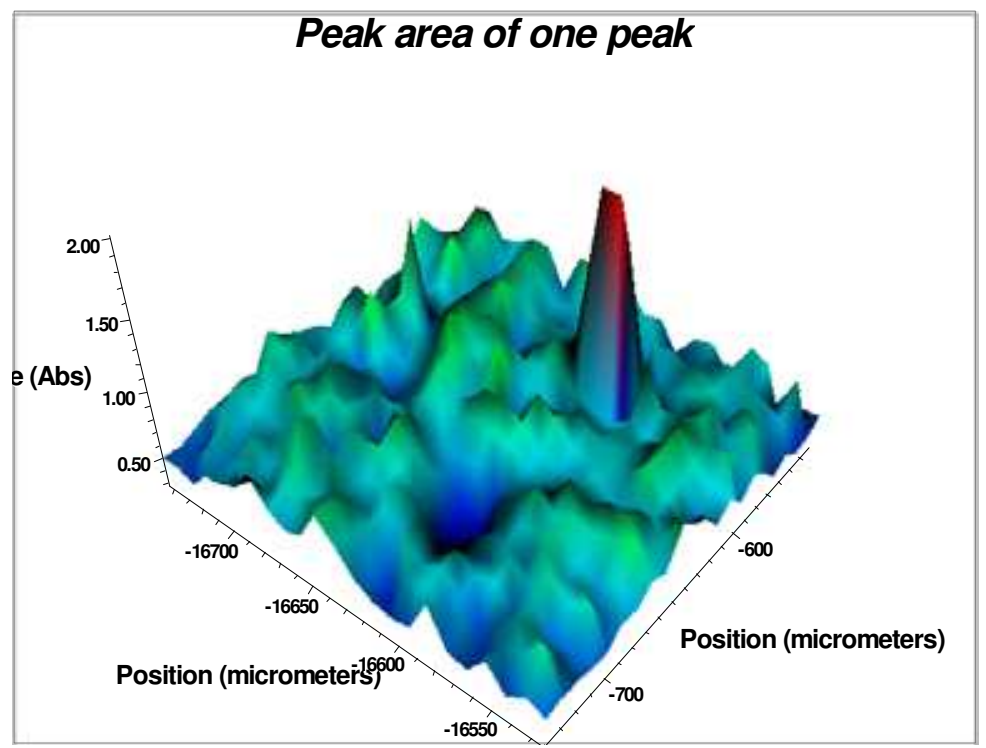

ca. $1420-1330 \mathrm{~cm}^{-1}$ (3D image) 
(c)

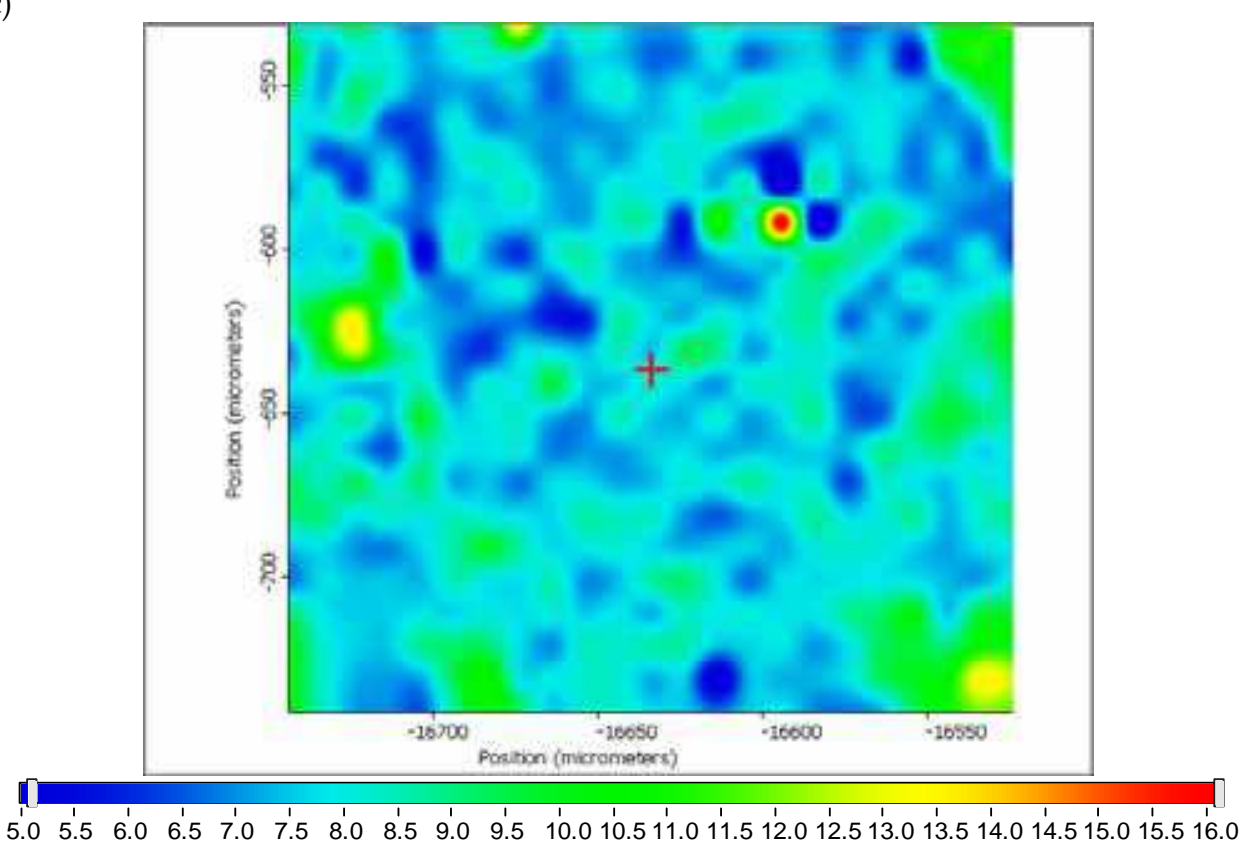

ca. $1185-950 \mathrm{~cm}^{-1}$ (Chemical image; Ruler showing chemical intensity)

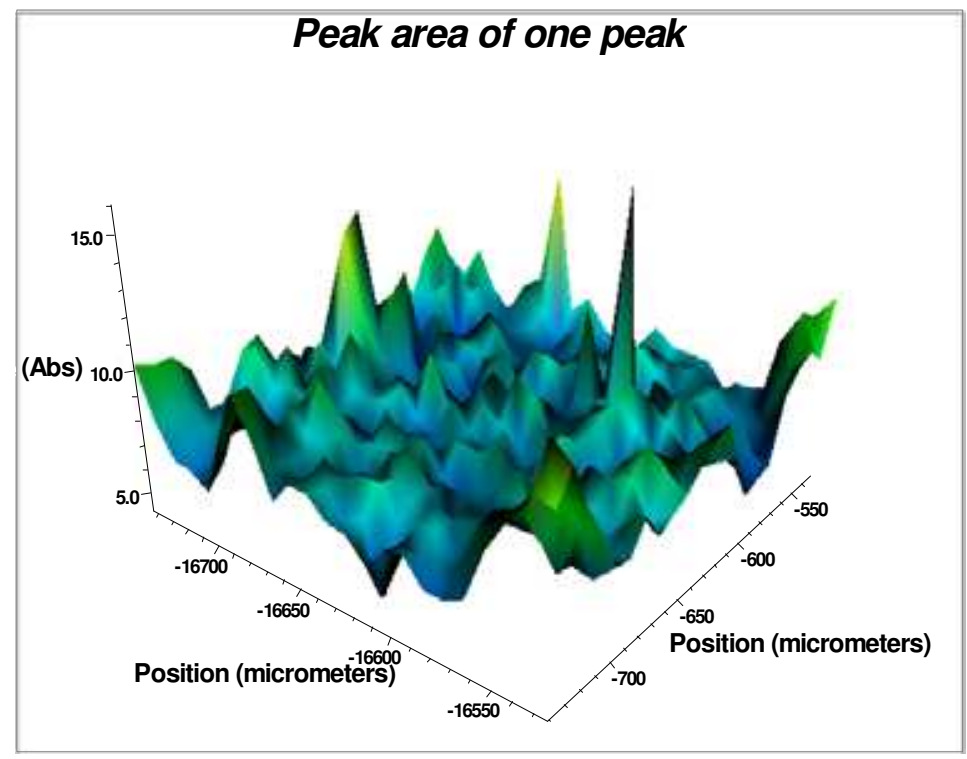

ca. $1185-950 \mathrm{~cm}^{-1}$ (3D image) 
(d)

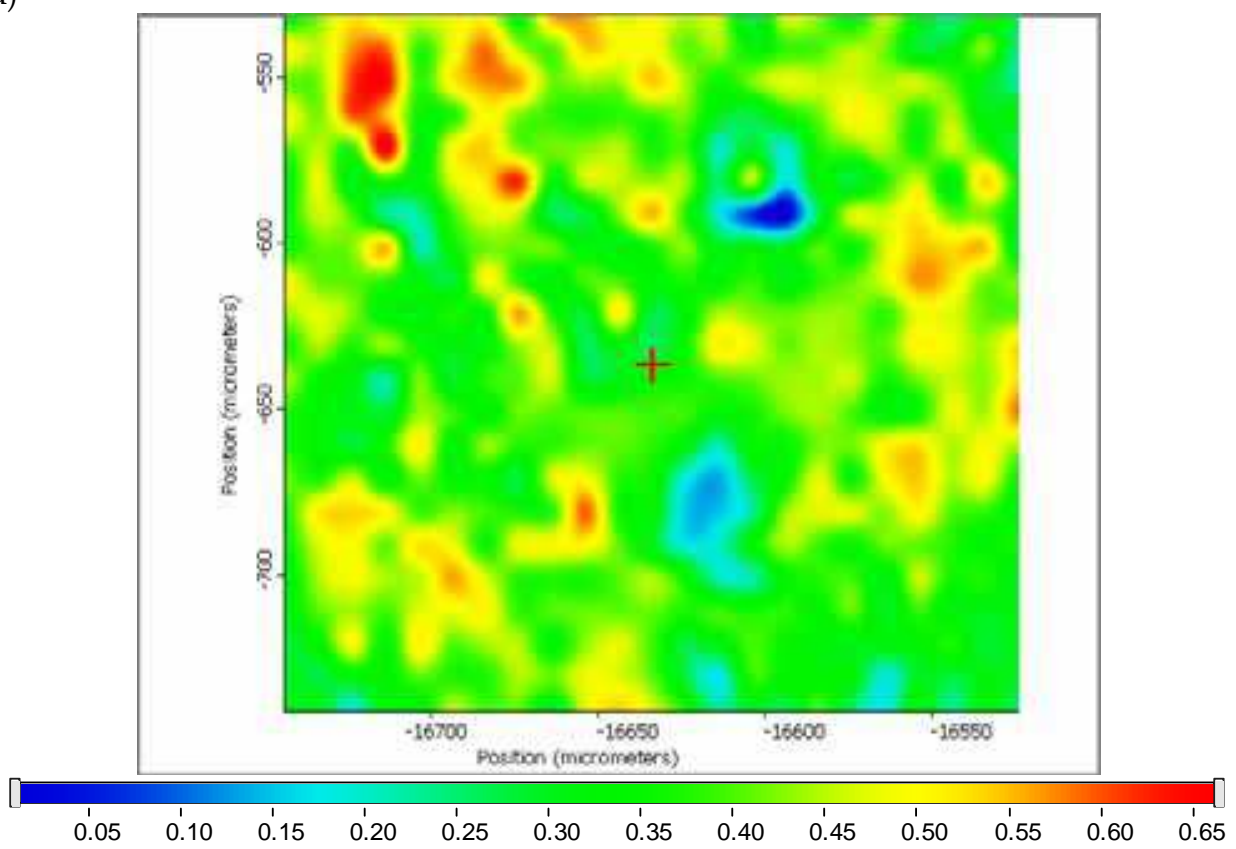

ca. 1628 cm-1 (Chemical image; Ruler showing chemical intensity)

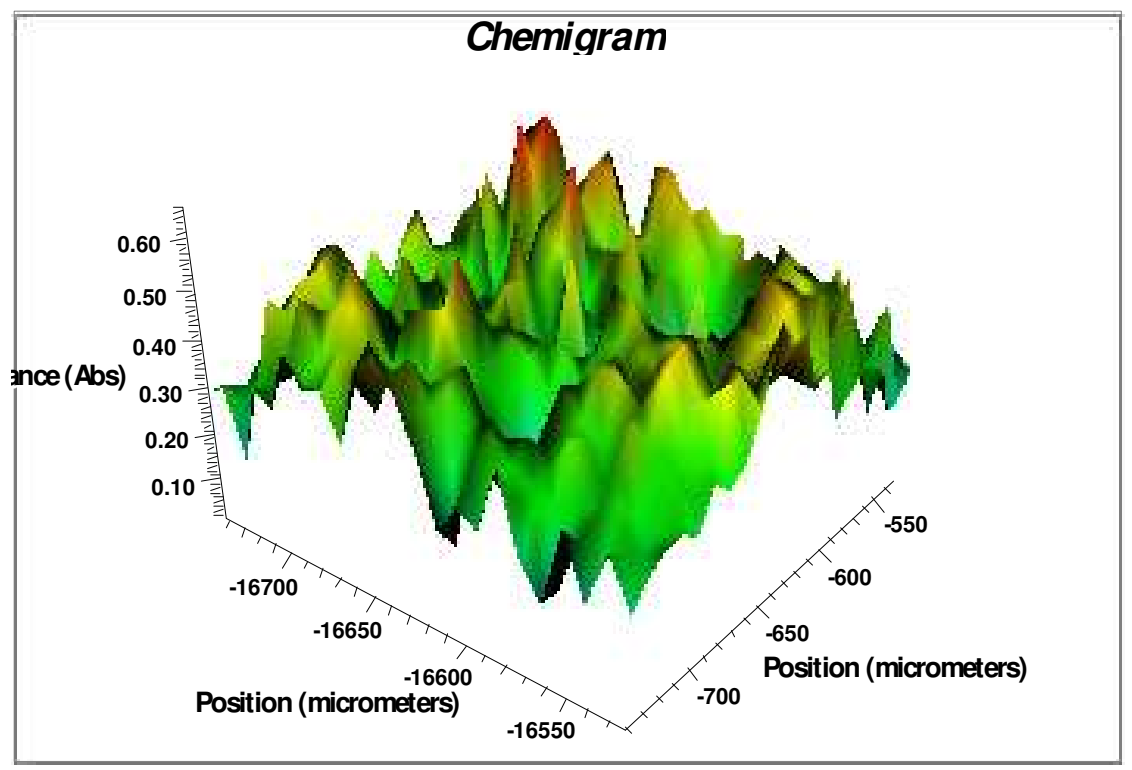

ca. $1628 \mathrm{~cm}^{-1}$ (3D image) 
(e)

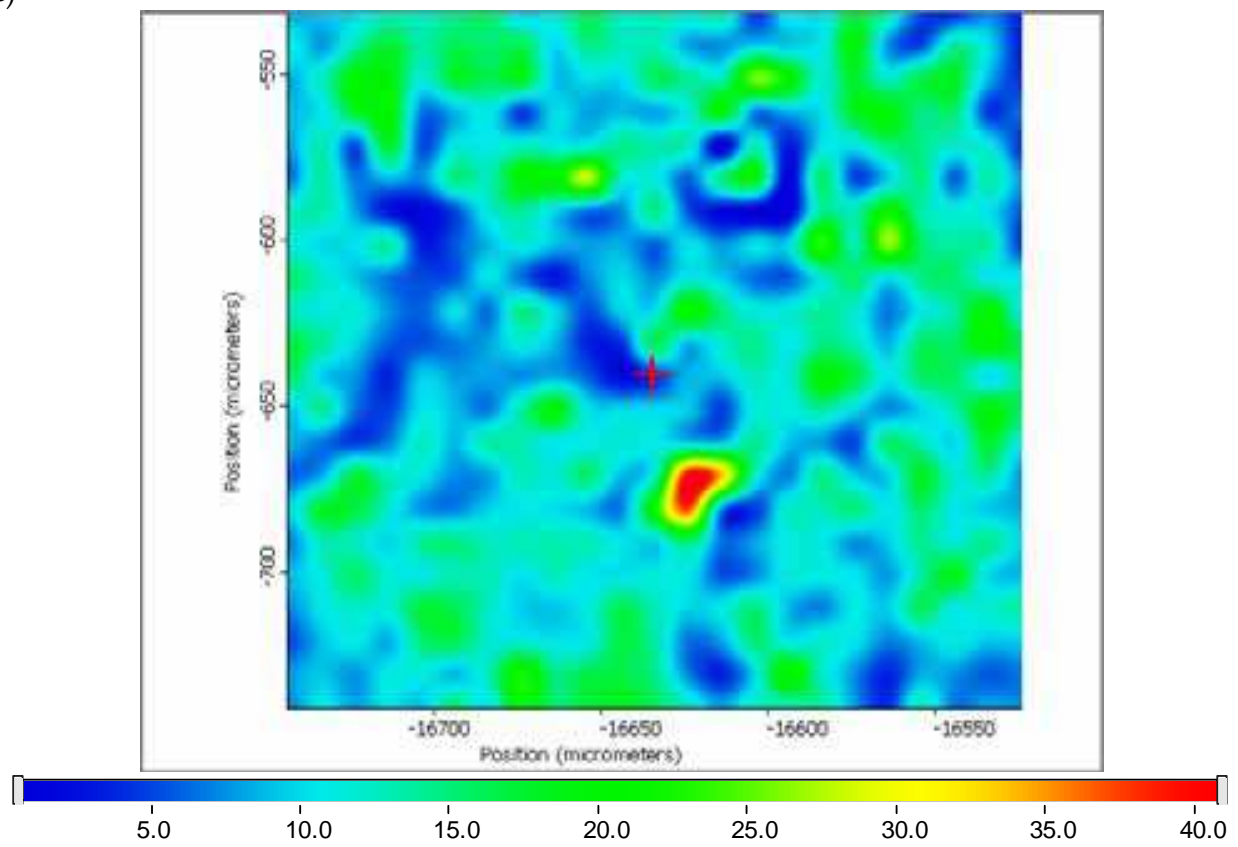

$\mathrm{CH}_{3}, \mathrm{CH}_{2}$ (peak center 2960, 2929, 2877, $2848 \mathrm{~cm}^{-1}$ ) (Chemical image; Ruler showing chemical intensity)

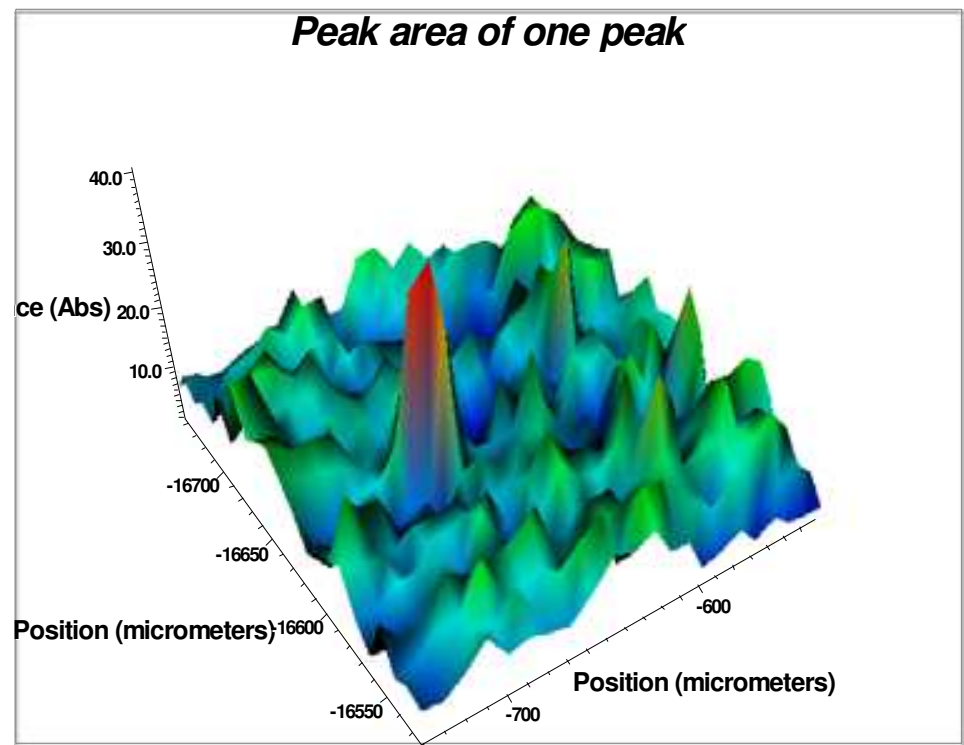

$\mathrm{CH}_{3}, \mathrm{CH}_{2}$ (peak center 2960, 2929, 2877, $2848 \mathrm{~cm}^{-1}$ ) (3D image) 
(f)

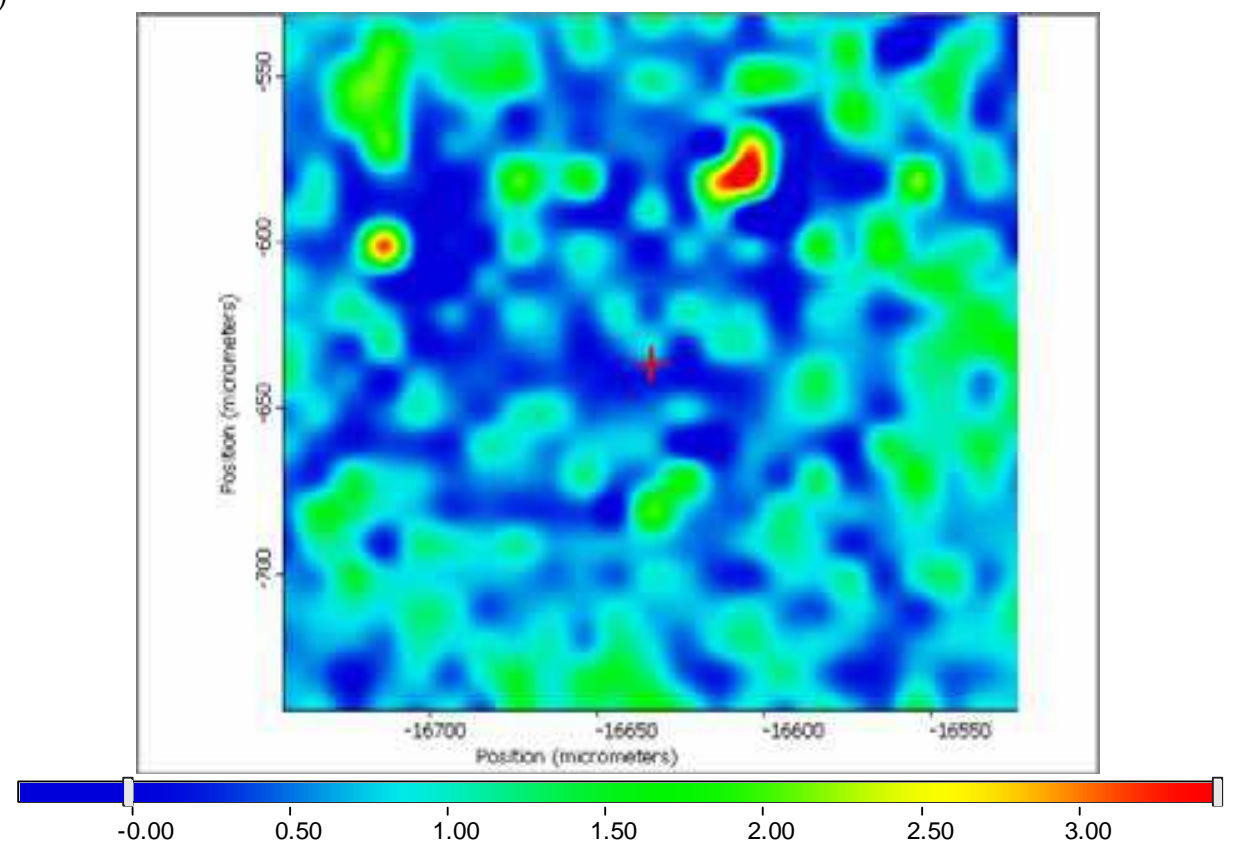

ca, $2956 \mathrm{~cm}^{-1}$ (Chemical image; Ruler showing chemical intensity)

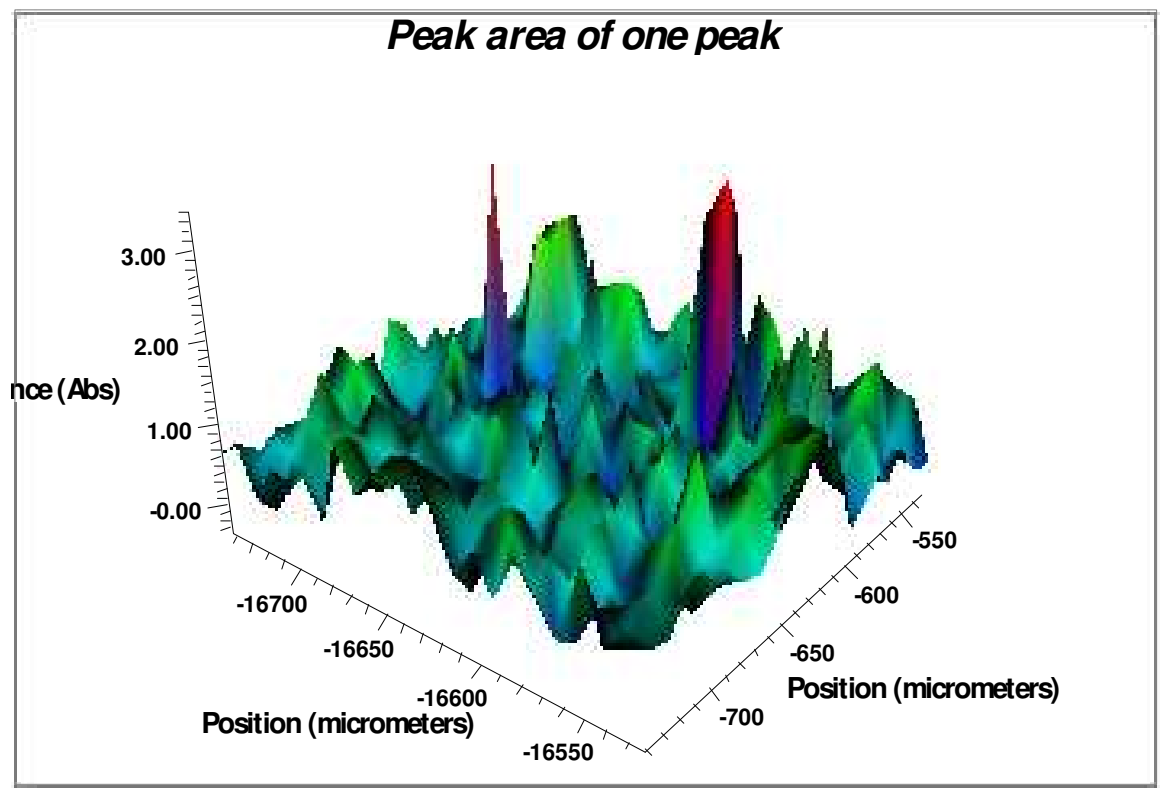

ca, $2956 \mathrm{~cm}^{-1}$ (3D image) 
(g)

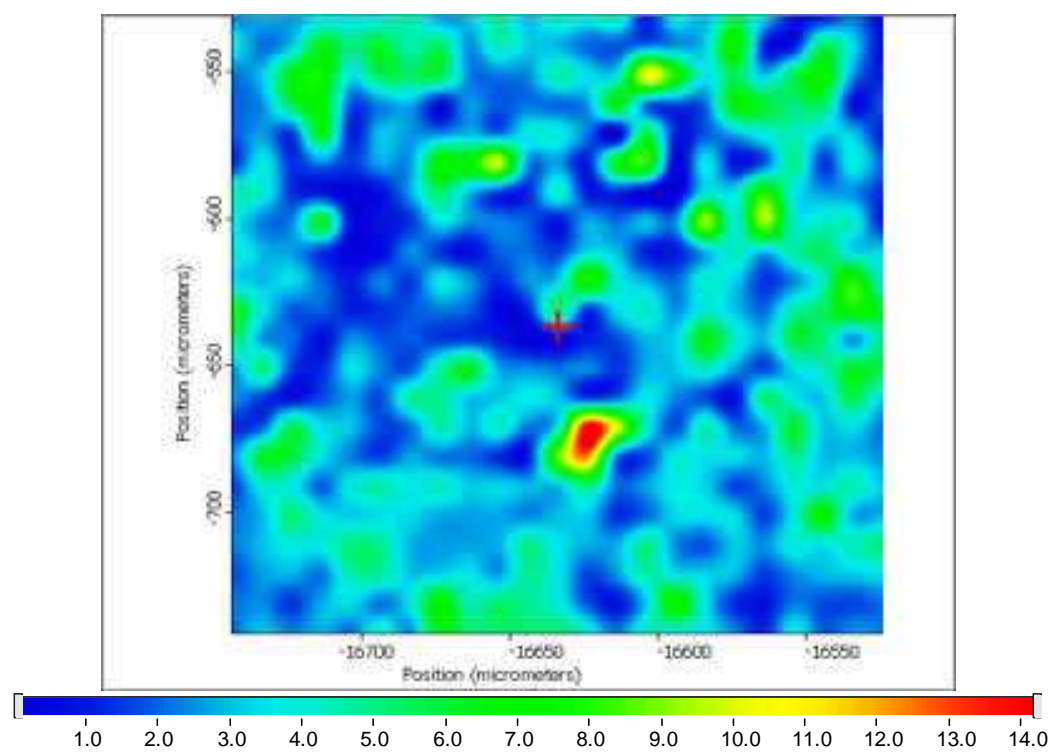

ca, $2920 \mathrm{~cm}^{-1}$ (Chemical image; Ruler showing chemical intensity)

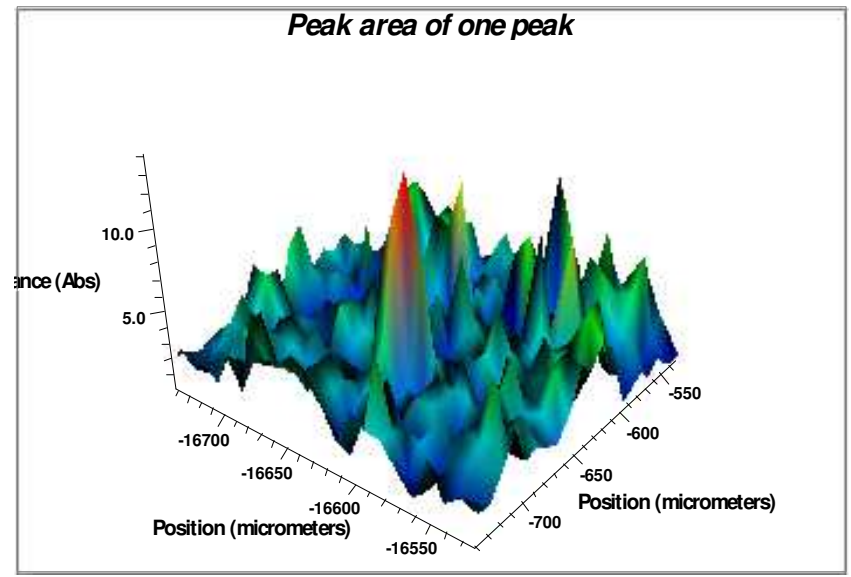

3D image at ca, $2920 \mathrm{~cm}^{-1}$ (3D image)

Fig. 4. Visible and molecular chemical images of the germ tissue in sorghum seed (pixel size $10 \times 10 \mu \mathrm{m}$ ) using ultra-spatially resolved synchrotron-radiation based infrared microspectroscopy at National Synchrotron Light Source, Brookhaven National Lab (U.S. Dept of Energy, NY): (a) area under ca. $1650 \mathrm{~cm}^{-1}$ peak (amide I); (b) area under ca. $1380 \mathrm{~cm}^{-1}$ peak (region: 1420-1330) $\mathrm{cm}^{-1}$ region (cellulosic compounds); (c) area under $1080 \mathrm{~cm}^{-1}$ peak (CHO); (d) area under ca. $1628 \mathrm{~cm}^{-1}$ peak (protein $2^{\text {nd }}$ structure beta-sheet); (e) area under $\mathrm{CH}$ region $\mathrm{cm}^{-1}$; (e) area under $2956 \mathrm{~cm}^{-1}$ peak $\left(\mathrm{CH}_{3}\right.$ anti-symmetric stretching band); $(\mathrm{g})$ area under $2956 \mathrm{~cm}^{-1}$ peak $\left(\mathrm{CH}_{2}\right.$ anti-symmetric stretching band). 


\subsection{Molecular chemistry mapping of functional groups ratio}

Not only each molecular functional group in biopolymers could be imaged with the synchrotron SR-IMS, but also molecular functional group ratios. Figure 5 shows the visible (a) and molecular chemical functional group ratio images of the embryo (germ) tissue in sorghum seed (pixel size $10 \times 10 \mu \mathrm{m}$ ): (b) peak area ratio images of amide I (ca. $1650 \mathrm{~cm}^{-1}$ ) to total carbohydrate (ca. 1185-950 $\mathrm{cm}^{-1}$ ) region; (c) peak area ratio images of protein $2^{\text {nd }}$ structure a helix $\left(1657 \mathrm{~cm}^{-1}\right)$ to $\beta$ sheet $\left(1628 \mathrm{~cm}^{-1}\right)$ ratio; (d) peak area ratio of amide I (ca. $1650 \mathrm{~cm}^{-1}$ to $\mathrm{CHO}\left(1067 \mathrm{~cm}^{-1}\right)$ using ultra-spatially resolved synchrotron-based FTIR microspectroscopy. The amide I band arises predominantly from the $\mathrm{C}=\mathrm{O}$ stretching vibration of the amide $\mathrm{C}=\mathrm{O}$ group. The frequency of the amide $\mathrm{I}$ band is particularly sensitive to protein secondary structure $(5,7,14)$ and can be used to predict protein secondary structure. The amide II (predominantly an $\mathrm{N}-\mathrm{H}$ bending vibration coupled to C$\mathrm{N}$ stretching) is also used to assess protein conformation. However, as it arises from complex vibrations involving multiple functional groups, it is less useful for protein structure prediction than the amide I $(2,8,9)$. No any publication has been found to map the embryo tissue in the literature. This is the first time to use the synchrotron (SR-IMS) as a novel tool to "see" embryo tissue in a chemical sense.

(a)

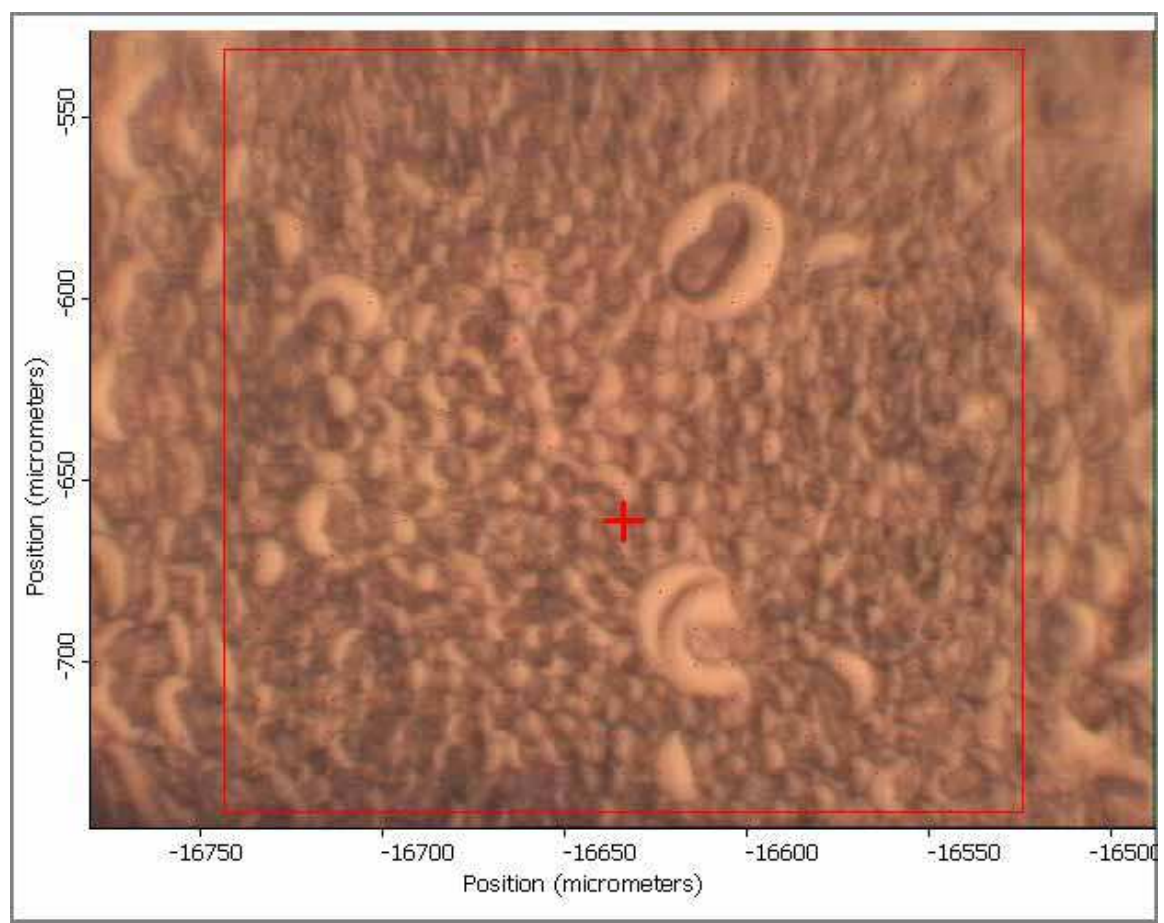

Visible image of selected germ area in sorghum seeds 
(b)

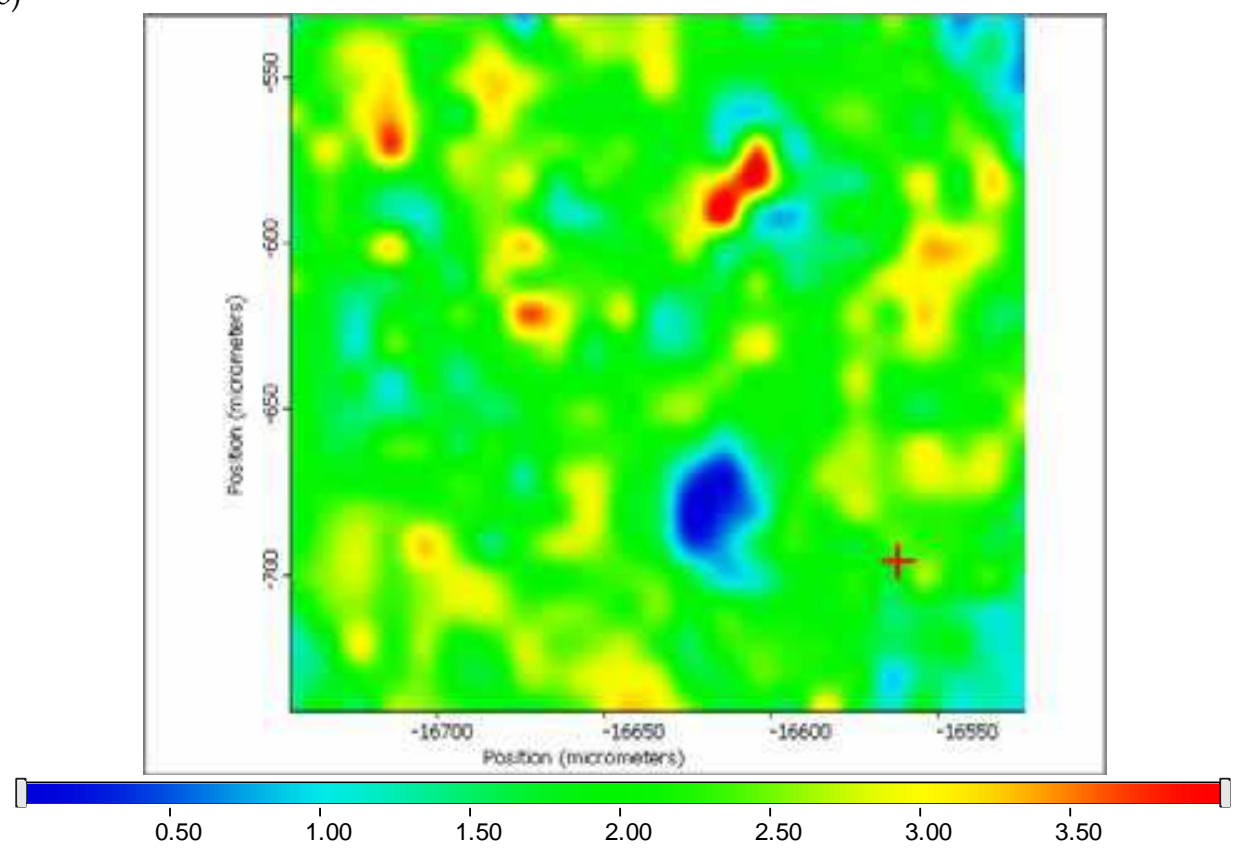

Peak area ratio at ca. 1650 / 1185-950 $\mathrm{cm}^{-1}$ (Chemical image)

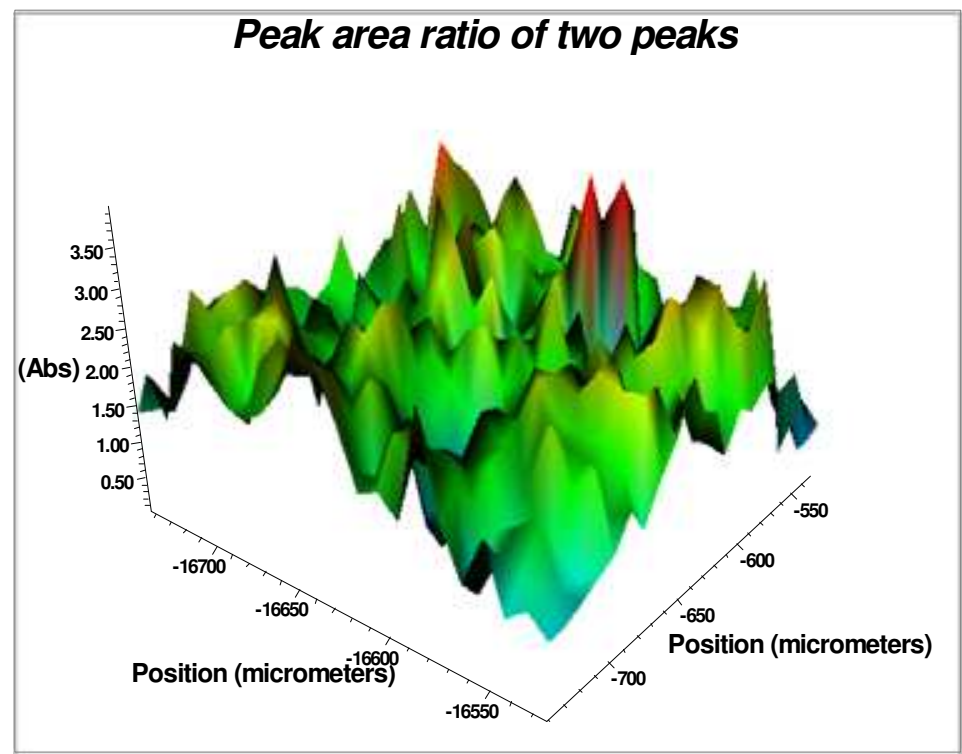

Peak area ratio at ca. 1650 / 1185-950 $\mathrm{cm}^{-1}$ (3D image) 
(c)

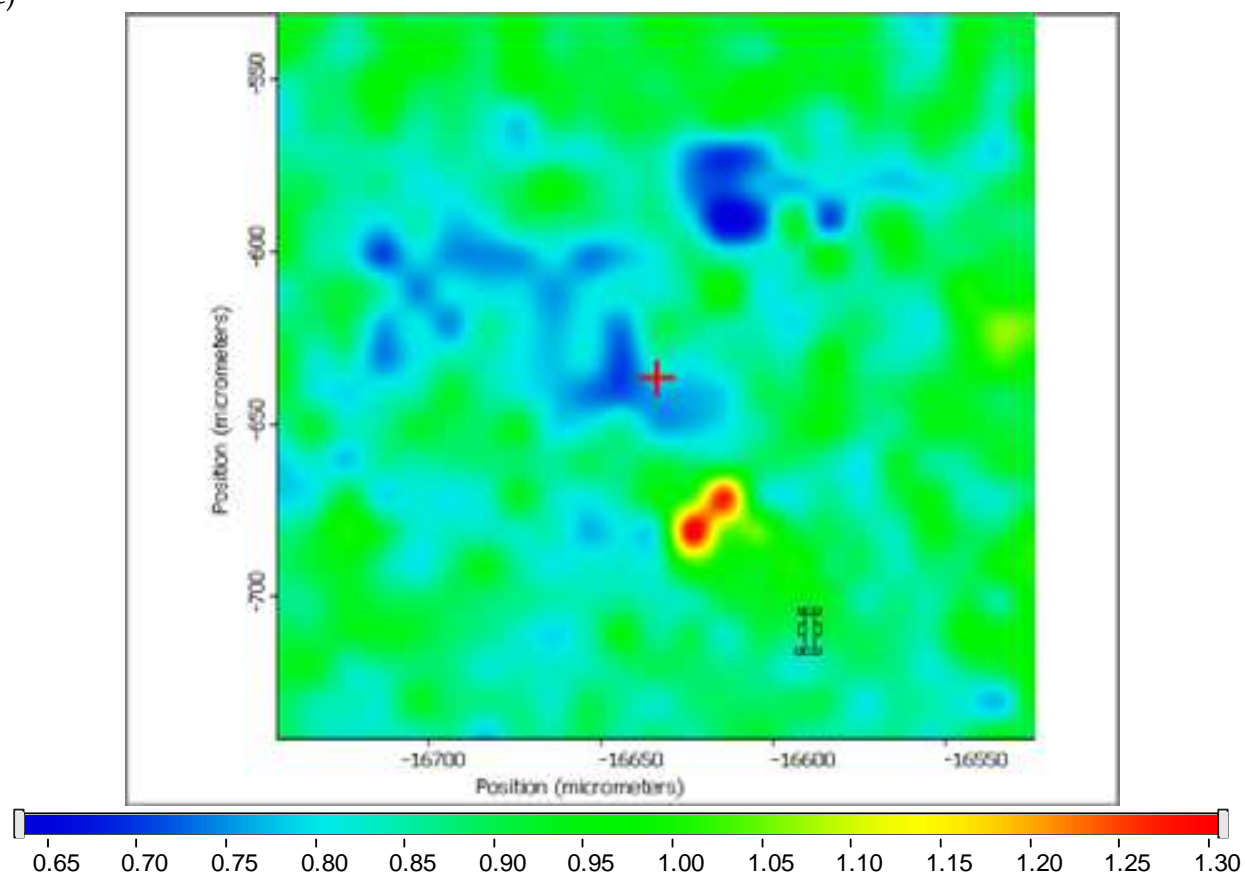

Peak height ratio ca. $1657 / 1628 \mathrm{~cm}^{-1}$ (Chemical image)

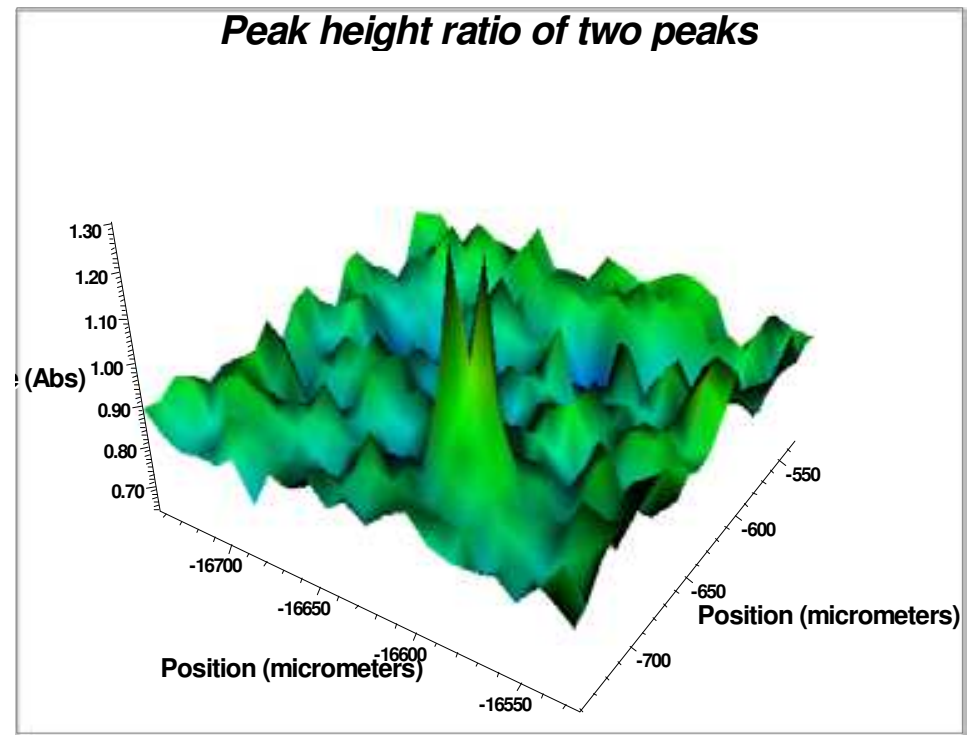

Peak height ratio ca. 1657/1628 cm-1 (3D image) 
(d)

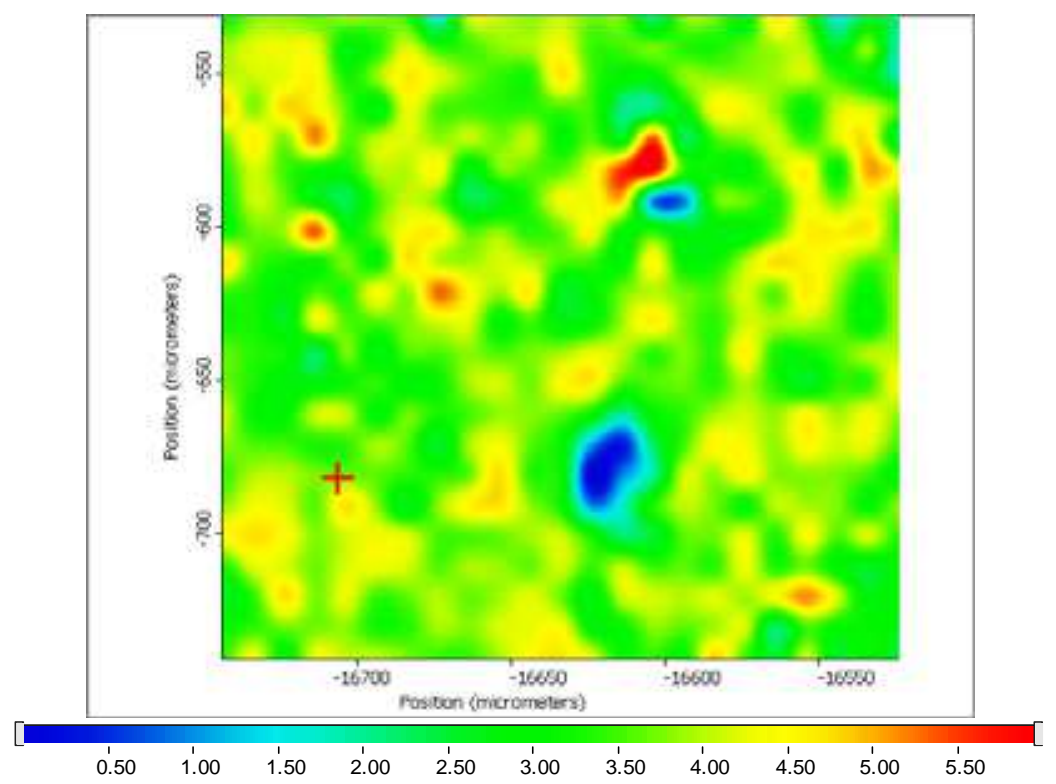

Peak area ratio ca. 1650/1067 $\mathrm{cm}^{-1}$ (Chemical image)

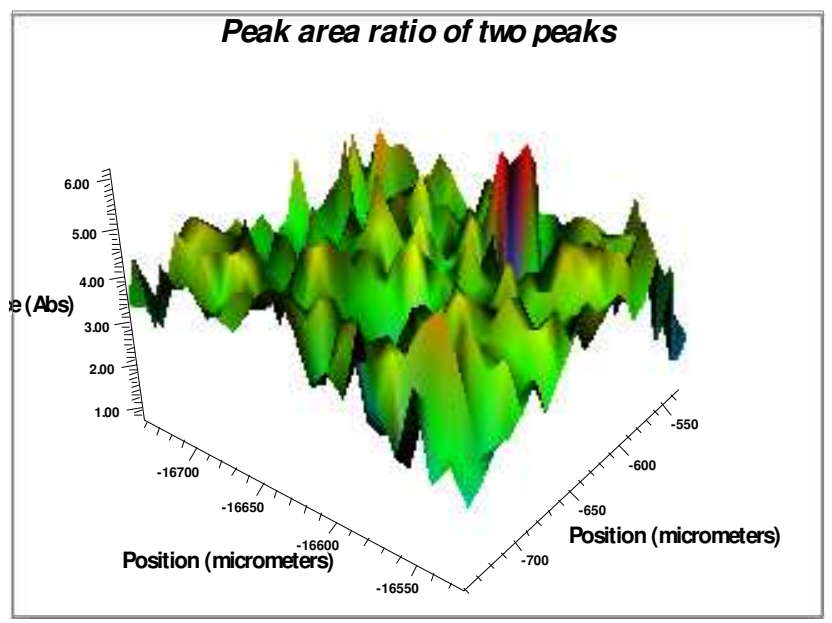

Peak area ratio ca. 1650/1067 $\mathrm{cm}^{-1}$ (3D image)

Fig. 5. Visible (a) and molecular chemical functional group ratio images of the germ tissue in sorghum seed (pixel size $10 \times 10 \mu \mathrm{m})$ : (b) Peak area ratio images of amide I $\left(1650 \mathrm{~cm}^{-1}\right)$ to carbohydrate (1185-950 $\left.\mathrm{cm}^{-1}\right)$ region; (c) Peak area ratio images of protein $2^{\text {nd }}$ structure $\alpha$ helix $\left(1657 \mathrm{~cm}^{-1}\right)$ to $\beta$ sheet $\left(1628 \mathrm{~cm}^{-1}\right)$ ratio; (d) Peak area ratio of amide I to $1067 \mathrm{~cm}^{-1}$, using ultra-spatially resolved synchrotron-based FTIR microspectroscopy at National Synchrotron Light Source, Brookhaven National Lab (U.S. Dept of Eenergy, NY). 


\section{Conclusions and implications}

In conclusion, with the synchrotron SR-IMS, the molecular chemistry within intact embryo (germ) tissue could be imaged within cellular dimensions. The intensity and distribution of the various chemical functional groups of $\mathrm{CH}_{3}$ (ca. $2956 \mathrm{~cm}^{-1}$ ) and $\mathrm{CH}_{2}$ antisymmetric stretching bands (ca. $2920 \mathrm{~cm}^{-1}$ ), amide I (ca. $1650 \mathrm{~cm}^{-1}$ ), amide II (ca. $1550 \mathrm{~cm}^{-1}$ ), protein secondary structures (ca. 1657, $1628 \mathrm{~cm}^{-1}$ ), cellulosic compounds (ca. 1420-1330 $\mathrm{cm}^{-1}$ ), and carbohydrate compounds $\left(1185-950 \mathrm{~cm}^{-1}\right)$ as well as the functional group ratio could be chemically mapped. To my knowledge, this is the first time that the embryo (germ) tissue could be "seen" in a chemical sense without destruction of inherent structure at cellular dimensions with the synchrotron-based analytical technique (SR-IMS)

\section{Acknowledgments}

This research has been supported by grants from Natural Sciences and Engineering Research Council of Canada (NSERC- Individual Discovery Grant), Saskatchewan Agricultural Development Fund (ADF) and Ministry of Agriculture Strategic Research Chair fund. The National Synchrotron Light Source in Brookhaven National Laboratory (NSLSBNL, New York, USA) is supported by the U.S. Department of Energy contract DE-AC0298CH10886. The Center for Synchrotron Biosciences, The Center for Proteomics at Case Western Reserve University is supported by the National Institute for Biomedical Imaging and Bioengineering under P41-EB-01979. We are grateful to Dr. Dasen Liu (visiting professor, Northeast Agricultural University) for providing Chinese sorghum seeds (feedtype), Megan Bourassa, Jennifer Bohon, Nebojsa Marinkovic, Adele Qi Wang, Lisa Miller (NSLS-BNL, New York, USA) for helpful data collection at U2B and U10B experimental stations, and Tim May for helpful data collection and discussion at 01B1-1 station, Canadian Light Sources (CLS).

\section{References}

[1] Miller, L. M.; Dumas, P. Chemical imaging of biological tissue with synchrotron infrared light. Biochim. Biophys. Acta. 2006, 1758, 846-857.

[2] Yu, P. Plant-Based Food and Feed Protein Structure Changes Induced by GeneTransformation, Heating and Bio-Ethanol Processing: A Novel Synchrotron-Based Molecular Structure and Nutrition Research Program. Mol. Nutr. Food Res. 2010, In press (Invited)

[3] Marinkovic, N. S.; Chance, M. R. Synchrotron Infrared Microspectroscopy. In: Meyers, R. (Ed), Encyclopedia of Molecular Cell Biology and Molecular Medicine, 2nd ed., Vol 13, Wiley Inc. 2006, pp 671-708.

[4] Wetzel, D. L.; Eilert, A. J.; Pietrzak, L. N.; Miller, S. S.; Sweat, J. A. Ultraspatially resolved synchrotron infrared microspectroscopy of plant tissue in situ. Cell. Mol. Bio. 1998, 44, 145-167.

[5] Budevska, B. O. Applications of Vibrational Spectroscopy in Life, Pharmaceutical and Natural Sciences. In: Chalmers, J. M., Griffiths, P. R. (Eds). Handbook of Vibrational Spectroscopy, Vol. 5. John Wiley and Sons, Inc., New York, NY, USA, 2002, pp 3720-3732. 
[6] Yu, P.; McKinnon, J. J.; Christensen, C. R.; Christensen, D. A. 2004. Imaging molecular chemistry of Pioneer corn. J. Agric. Food Chem. 2004, 52, 7345-7352.

[7] Stewart, D., McDougall, G.J.; Baty, A. Fourier transform infrared microspectroscopy of Anatomically Different Cells of Falx (Linum usitatissimum) stems during development. J. Agric. Food Chem. 1995. 43, 1853-1858.

[8] Jackson, M.; Mantsch, H. H. The use and misuse of FTIR spectroscopy in the determination of protein structure. Biochemistry and Molecular Biology. 1995. 30: 95-120.

[9] Jackson, M., Mantsch, H. H., Biomedical Infrared Spectroscopy, In: Mantsch, H. H., Chapman, D. (Eds), Infrared Spectroscopy of Biomolecules, Wiley-Liss, New York, 1996, pp 311-340.

[10] Marinkovic, N. S.; Huang, R., Bromberg, P.; Sullivan, M.; Toomey, J.; Miller, L. M.; Sperber, E.; Moshe, S.; Jones, K. W.; Chouparova, E.; Lappi, S.; Franzen, S.; Chance, M. R. Center for Synchrotron Biosciences' U2B beamline: an international resource for biological infrared spectroscopy. J. Synchrotron Rad. 2002. 9, 189-197.

[11] Doiron, K. J.; Yu, P.; Christensen, C. R.; Christensen, D. A.; McKinnon, J. J. Detecting molecular changes in Vimy flaxseed protein structure using synchrotron FTIRM and DRIFT spectroscopic techniques: Structural and biochemical characterization. Spectroscopy. 2009. 23, 307-322.

[12] Himmelsbach, D. S.; Khalili, S.; Akin, D. E. FT-IR microspectroscopic imaging of flax (linum usitatissimum L.) stems. Cell. Mol. Bio. 1998, 44, 99-108.

[13] Raab, T.K; Martin, M.C. Visualizing rhizosphere chemistry of legumes with midinfrared synchrotron radiation. Planta. 213, 881-887.

[14] Colthup, N. B.; Daly, L.H.; Wiberley, S. E.. Introduction to infrared and Raman spectroscopy. 3rd ed. Academic Press, Boston, 1990, pp 547.

[15] Yu, P.; Christensen, C.R.; Christensen, D.A.; McKinnon, J.J. Ultrastructural-chemical makeup of yellow- (Brassica Rapa) and brown-seeded (Brassica Napus) canola within cellular dimensions, explored with synchrotron reflection FTIR microspectroscopy. Can. J. Plant Sci. 2005, 85, 533-541 


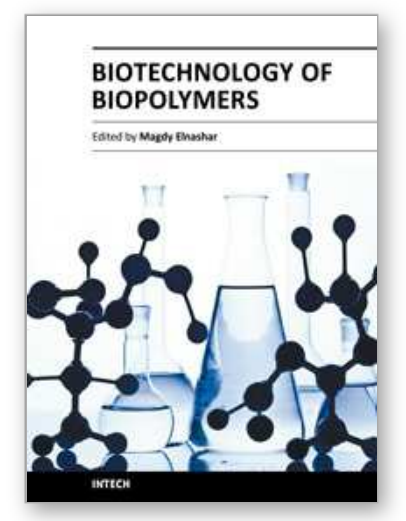

\author{
Biotechnology of Biopolymers \\ Edited by Prof. Magdy Elnashar
}

ISBN 978-953-307-179-4

Hard cover, 364 pages

Publisher InTech

Published online 24, June, 2011

Published in print edition June, 2011

The book "Biotechnology of Biopolymers" comprises 17 chapters covering occurrence, synthesis, isolation and production, properties and applications, biodegradation and modification, the relevant analysis methods to reveal the structures and properties of biopolymers and a special section on the theoretical, experimental and mathematical models of biopolymers. This book will hopefully be supportive to many scientists, physicians, pharmaceutics, engineers and other experts in a wide variety of different disciplines, in academia and in industry. It may not only support research and development but may be also suitable for teaching. Publishing of this book was achieved by choosing authors of the individual chapters for their recognized expertise and for their excellent contributions to the various fields of research.

\title{
How to reference
}

In order to correctly reference this scholarly work, feel free to copy and paste the following:

Peiqiang Yu (2011). SR-IMS Molecular Spectroscopic Image of Functional Groups in Biopolymers in Feed Systems, Biotechnology of Biopolymers, Prof. Magdy Elnashar (Ed.), ISBN: 978-953-307-179-4, InTech, Available from: http://www.intechopen.com/books/biotechnology-of-biopolymers/sr-ims-molecularspectroscopic-image-of-functional-groups-in-biopolymers-in-feed-systems

\section{INTECH}

open science | open minds

\section{InTech Europe}

University Campus STeP Ri

Slavka Krautzeka 83/A

51000 Rijeka, Croatia

Phone: +385 (51) 770447

Fax: +385 (51) 686166

www.intechopen.com

\section{InTech China}

Unit 405, Office Block, Hotel Equatorial Shanghai

No.65, Yan An Road (West), Shanghai, 200040, China

中国上海市延安西路65号上海国际贵都大饭店办公楼 405 单元

Phone: +86-21-62489820

Fax: +86-21-62489821 
(C) 2011 The Author(s). Licensee IntechOpen. This chapter is distributed under the terms of the Creative Commons Attribution-NonCommercialShareAlike-3.0 License, which permits use, distribution and reproduction for non-commercial purposes, provided the original is properly cited and derivative works building on this content are distributed under the same license. 